\title{
Lactoseries Carbohydrates Specify Subsets of Dorsal Root Ganglion Neurons Projecting to the Superficial Dorsal Horn of Rat Spinal Cord ${ }^{1}$
}

\author{
JANE DODD ${ }^{2}$ AND THOMAS M. JESSELL ${ }^{3}$ \\ Department of Neurobiology, Harvard Medical School, Boston, Massachusetts 02115
}

\begin{abstract}
Cell surface carbohydrates are thought to play important roles in the development and differentiation of mammalian cells. In previous studies we have found that one population of dorsal root ganglion (DRG) neurons is specified by the expression of complex globoseries oligosaccharides (Dodd, J., D. Solter, and T. M. Jessell (1984) Nature 311: 469-472; Jessell, T. M., and J. Dodd (1985) Philos. Trans. R. Soc. Lond. (Biol.) 308: 271-281). We now report that monoclonal antibodies (MAbs) directed against backbone structures of lactoseries oligosaccharides define antigens present in the cytoplasm of a second, anatomically and functionally distinct subset of DRG neurons. Lactoseries carbohydrate structures identified by MAb A5 are restricted to small- and intermediate-diameter DRG neurons with central projections in the superficial dorsal horn of the rat spinal cord. The distribution of labeled terminals suggests that many of the DRG neurons that express lactoseries carbohydrates are likely to convey nociceptive information. More complex galactose- and fucose-substituted lactoseries structures recognized by MAbs LD2, KH10, TC6, TD10, LA4, and anti-Lewis a are segregated on subsets of DRG neurons that differ in their expression of substance $P$, somatostatin, and fluoride-resistant acid phosphatase and in their laminar termination in the superficial dorsal horn. The majority of lactoseries carbohydrate antigens identified in the cytoplasm of DRG neurons are also expressed on the surface of subsets of DRG neurons in culture.
\end{abstract}

These studies establish that structurally defined carbohydrate differentiation antigens specify the majority of primary

Reccived February 15, 1985; Revised April 23, 1985;

Accepted May 6, 1985

\footnotetext{
1 This work was supported by National Institutes of Health Grants NS1/369 and NS20116, the National Multiple Sclerosis Society, the Muscular Dystrophy Association, the McKnight Foundation, the Rita Allen Foundation, and a DuPont Company faculty award. We are grateful to everyone who generously provided us with monoclonal antibodies against carbohydrate structures (see "Materials and Methods") and to P. Hamilton for preparing dorsal root ganglion cultures. We thank S. C. Landis, J. Magnani, E. R. Perl, D. Solter, and M. D. Womack for helpful discussions and comments on the manuscript. Dr. D. Baker (Chembiomed Ltd.) kindly performed solid phase and radial diffusion immunoassays to characterize the specificity of several of the antibodies used in this study. We also acknowledge $R$. Oriol for making available preprints of unpublished work and for valuable discussion of the expression and structure of carbohydrate antigens on sensory cells.

${ }^{2}$ To whom correspondence should be sent, at her present address: Department of Physiology, Columbia University, College of Physicians and Surgeons, 630 West 168th Street, New York, NY 10032.

${ }^{3}$ Present address: Howard Hughes Medical Institute College of Physicians and Surgeons, Columbia University, New York, NY 10032
}

sensory neurons with cutaneous receptive fields. Moreover, lactoseries carbohydrate structures similar or identical to those expressed on neonatal DRG neurons in culture have been implicated in cell-cell interactions at early stages of preimplantation embryonic development. Our observations suggest strategies for testing the hypothesis that carbohydrates present on the surface of subsets of DRG neurons play a role in cell interactions that contribute to the laminar organization of sensory afferents in the developing spinal cord.

The transmission of cutaneous sensory information from the periphery to the spinal cord is mediated by sensory neurons located in the dorsal root ganglia (DRG). Analysis of the receptive properties of cutaneous sensory endings has established the existence of more than a dozen functional subpopulations of DRG neurons, each of which can be activated by discrete types of cutaneous stimuli (lggo, 1976; Light and Perl, 1984). Functionally distinct classes of cutaneous sensory afferents exhibit restricted and stereotyped patterns of axon collateral arborization in the dorsal horn of the spinal cord that can be correlated with the laminar cytoarchitecture of the spinal cord (Brown, 1981; Perl, 1983). Thus, the central terminals of nociceptive primary afterents are located predominantly within lamina I (the marginal zone) and lamina II (the substantia gelatinosa) (Rethelyi, 1977; Light and Perl, 1979; Ribiero Da Silva and Coimbra, 1982), whereas the majority of low threshold mechanoreceptive afferents terminate within laminae III and IV (the nucleus proprius) of the dorsal horn (Brown et al., 1977; Semba et al., 1983; Ralston et al., 1984).

Within rat DRG, it has been possible to distinguish subpopulations of neurons by variations in somatic size and ultrastructure (Lawson et al., 1974; Rambourg et al., 1983). Histochemical and immunocytochemical studies have identified several cytoplasmic antigens that are restricted to subpopulations of large- and small-diameter DRG neurons (Dodd et al., 1983b; Lawson et al., 1984). The smallerdiameter DRG neurons in rats can be divided into three, virtually nonoverlapping, subsets based on the selective expression of the peptides substance $P(S P)$ and somatostatin (SOM) (Hokfelt et al., 1976) and a sensory neuron-specific acid phosphatase isoenzyme, fluoride-resistant acid phosphatase (FRAP) (Nagy and Hunt, 1982; Dodd et al., 1983a, b). No direct correlation between sensory modality and neuronal morphology or cytochemistry has yet been demonstrated. However, the laminar segregation, in the dorsal horn, of afferent terminals that express these cytoplasmic markers (Nagy and Hunt, 1983) suggests that they are likely to be present in functionally distinct neuronal populations.

Clarification of the anatomical organization of cutaneous sensory projections has provided little information on the cellular interactions during development that contribute to the lamination of sensory input in the spinal cord. It seems likely, however, that the generation of 
appropriate afferent synaptic connections in the dorsal horn is dependent on intercellular recognition between subsets of sensory and spinal neurons. Such interactions may be mediated, at least in part, by cell surface molecules located selectively on subsets of primary sensory neurons. Although the existence and chemical nature of such molecules remain to be established, recent studies using monocional antibodies (MAbs) to define cell types within the nervous system have revealed that many discriminatory neural cell surface markers are carbohydrate in nature (Raff et al., 1979; Mirsky, 1982).

We have begun to test the possibility that cell surface carbohydrate slruclures specify functional sets of primary sensory neurons and contribute to the organization of sensory afferents in the developing spinal cord. In support of this, we have demonstrated that DRG neurons with central projections in laminae III and IV of the dorsal horn can be identified by the expression of complex globoseries carbohydrate structures (Dodd et al., 1984; Jessell and Dodd, 1985). In this paper we show that carbohydrate epitopes associated with lactoseries oligosaccharides are also expressed, highly selectively, in the cytoplasm and on the surface of distinct subsets of DRG neurons. Sensory neurons that express individual lactoseries carbohydrate epitopes project to restricted laminar domains in laminae I and II of the dorsal horn. Moreover, the expression of defined lactoseries carbohydrate sequences is correlated with neuropeptides and other chemical markers that appear to delineate functional subclasses of DRG neurons.

\section{Materials and Methods}

Immunocytochemistry. Adult CD rats (100 to $200 \mathrm{gm}$ ) were anesthetized with urethane or pentobarbitone and fixed by cardiac perfusion with $50 \mathrm{ml}$ of ice-cold saline followed by $500 \mathrm{ml}$ of ice-cold $4 \%$ paraformaldehyde in 0.1 $M$ phosphate buffer (PB), pH 7.2, or by Bouin's fixative. The spinal cord and DRG were rinsed overnight in PB containing $30 \%$ sucrose. For preparation of fresh frozen sections, rats were killed and quickly perfused with $50 \mathrm{ml}$ of ice-cold saline and kept at $4^{\circ} \mathrm{C}$ during dissection. In some experiments, acetone-fixed sections were prepared by immersion of fresh frozen sections in acetone at $-21^{\circ} \mathrm{C}$ for 1 to $3 \mathrm{hr}$. Sections were then dried at $-21^{\circ} \mathrm{C}$ and proccssed. Cryostat sections $(5$ to $10 \mu \mathrm{m})$ of fresh frozen or fixed tissue were dried on gelatin-subbed slides and incubated for 18 to $24 \mathrm{hr}$ at $4^{\circ} \mathrm{C}$ with MAbs in tissue culture supernatant or in purified ascites fluid (diluted 1:1 for supernatant and 1:100 to 1:300 for ascites) in phosphate-buffered saline (PBS: $0.1 \mathrm{M}$ PB in $0.9 \%$ saline), pH 7.2 , containing $10 \%$ fetal calf serum and, with fixed tissue, $0.1 \%$ Triton $X-100$. After incubation, sections were washed with PBS containing $2 \%$ normal goat serum (NGS) and incubated with fluorescein isothiocyanate (FITC)- or rhodamine (Rh)-labeled goat anti-mouse lgM or lgG diluted $1: 75$ in PBS/NGS for 30 min at $22^{\circ} \mathrm{C}$. Sections were washed in PBS/NGS and coverslipped in $50 \%$ glycerol in $0.1 \mathrm{M}$ sodium carbonate buffer, $\mathrm{pH} 9.0$, containing $0.4 \mathrm{mg} / \mathrm{ml}$ of $p$-phenylenediamine.

Dual-color immunofluorescence studies were performed by simultaneous incubation of sections with a MAb and a rabbit antiserum or with MAbs of different subclasses, under the conditions described above. IgM subclass MAbs were visualized with FITC-goat anti-mouse IgM (1:75 dilution); lgG subclass MAbs were detected with subclass-specific rabbit anti-mouse antibodies (1:30) followed by Rh-goat anti-rabbit antibodies (1:200). Rabbit antisera were detected with Rh-goat anit-rabbit anlibudies (1:200). Control experiments indicated that subclass-specific conjugates did not bind detectably to the inappropriate class of antibody and that there was no crossdetection between the FITC-and $\mathrm{Rh}$-selective filter sets. Immunofluorescence localization of antibodies was examined on a Zeiss standard microscope.

Acid phosphatase histochemistry. Fresh frozen or fixed sections of rat DRG and spinal cord ( 5 to $10 \mu \mathrm{m}$ ) were processed for immunocytochemistry as described above. After photography and removal of coverslips, the sections were washed for $15 \mathrm{~min}$ in $0.2 \mathrm{M}$ Tris-maleate buffer, $\mathrm{pH} 5.5$. Sections were then incubated for $90 \mathrm{~min}$ at $37^{\circ} \mathrm{C}$ in $0.1 \mathrm{M}$ Tris-maleate buffer containing $3.0 \mathrm{~mm}$ lead nitrate, $234 \mathrm{~mm}$ sucrose, and 2 to $5 \mathrm{~mm}$ thiamine monophosphate or guanosine 5'-monophosphate, $\mathrm{pH} 5.5$ (Dodd et al., $1983 \mathrm{~b})$. After washing in Tris-maleate, sections were incubated with $1 \%$ aqueous ammonium sulfide for $30 \mathrm{sec}$, washed in water, and dehydrated and coverslipped. The fields that had been examined for immunocytochemistry were relocated and photographed under phase and interference contrast optics.

Tissue culture. DRG neurons were isolated from neonatal rats and maintained in dissociated cell culture for periods of 10 to 56 days using previously described methods (Yamamoto et al., 1981). Briefly, DRG were dissected from rats in $\mathrm{Ca}^{2+} / \mathrm{Mg}^{2+}$-free medium and incubated in collagenase $(0.1 \mathrm{mg} /$ $\mathrm{ml}$ ) and trypsin $(0.1 \%)$ for $30 \mathrm{~min}$ at $37^{\circ} \mathrm{C}$. Ganglia were collected by centrifugation, and a single cell suspension was obtained by trituration with a fire-polished Pasteur pipette. The cell suspension was filtered through three layers of sterile lens paper, to remove clumps, and was plated onto $35-\mathrm{mm}$ tissue culture dishes treated with rat-tail collagen and conditioned medium obtained from cultures of bovine endothelial corneal cells. In some experiments DRG cells were plated onto Primaria (Falcon) dishes treated solely with bovine corneal cell-conditioned medium. The culture medium consisted of Ham's F12 mcdium supplemented with $5 \%$ heat-inactivated rat serum, $4 \%$ 17-day embryonic rat extract, glucose (44 mM), penicillin/streptomycin $(50 \mathrm{~N} / \mathrm{ml}), 2 \mathrm{~mm}$ glutamine, $1 \% 100 \times$ vitamin stock (Grand Island Biological Co., Grand island, NY), and purified $7 \mathrm{~S}$ nerve growth factor $(1 \mu \mathrm{g} / \mathrm{ml})$. Proliferation of non-neuronal cells was suppressed by addition of $10 \mu \mathrm{M}$ arabinosylcytosine for 24 to $48 \mathrm{hr}$ soon after plating, and at later times as required.

For immunocytochemistry, cultures were washed in HEPES-buffered balanced salt solution supplemented with $44 \mathrm{~mm}$ glucose and $0.1 \%$ bovine serum albumin (BSA). Cultures were incubated in MAb for 30 to $60 \mathrm{~min}$ at $22^{\circ} \mathrm{C}$ as described above. Cultures were then washed three times with BSS and incubated in appropriate fluorescently labeled second antibodies for 30 min at $22^{\circ} \mathrm{C}$. Cultures were washed three times in buffered BSS and, in some experiments, were fixed in $4 \%$ paraformaldehyde in $0.12 \mathrm{M} \mathrm{PB}, \mathrm{pH} 7.2$, for 15 to $20 \mathrm{~min}$, washed twice in $0.12 \mathrm{M} \mathrm{PB}$, and coverslipped in $50 \%$ glyccrol, $0.1 \mathrm{M}$ sodium carbonate, $\mathrm{pH} 9.0$, containing $0.4 \mathrm{mg} / \mathrm{ml}$ of $p$-phenylenedamine, as described above.

Surgery. Dorsal rhizotomies were performed under pentobarbilune artesthesia on 100 - to $200 \mathrm{gm}$ rats. A lumbar vertebral laminectomy was performed under microscopic observation, and the dorsal roots corresponding to lumbar segments $L 2$ to $L 6$ were sectioned with iridectomy scissors, 2 to $3 \mathrm{~mm}$ from the dorsal root entry zone. Seven to 21 days after rhizotomy, rats were anesthetized and fixed by perfusion with $4 \%$ paraformaldehyde, and the spinal cord was removed for immunocytochemical examination as described above

In some experiments, rats were treated with colchicine $(20 \mu \mathrm{g}$ in $10 \mu \mathrm{l})$ by injection into the intrathecal space overlying the lumbar spinal cord and into the muscle bed surrounding the lumbar DRG, 24 to $48 \mathrm{hr}$ before perfusion of the animals.

Nomenclature. The designation of small-, intermediate-, and large-diameter DRG neurons used in this study is based on the analysis of rat DRG neuron cell body cross-sectional area by Lawson et al. $(1974,1984)$. Small-diameter DRG neurons are defined here as those with cross-sectional areas of less than $450 \mu \mathrm{m}^{2}$, intermediate diameter as those with cross-sectional area between 451 and $710 \mu \mathrm{m}^{2}$, and large-diameter as those with cross-sectional areas greater than $710 \mu \mathrm{m}^{2}$. Neuronal cross-sectional area was calculated from camera lucida drawings. Since considerable overlap in the somatic diameter of cytochemically defined subsets of DRG neurons has been reported (Lawson et al., 1984), the terms small, intermediate, and large are used to provide an indication of cell size rather than to imply the presence of distinct subpopulations. The laminar nomenclature for the rat superficial dorsal horn used in this paper incorporates the terminology of Ribiero Da Silva and Coimbra (1982) and the immunocytochemical analysis of Nagy and Hunt (1983).

Hybridoma production. MAbs were generated by immunization of BALB/ $c$ mice with a rat pancreatic acinar cell line, AR4-2J (Jessup and Hay, 1981), and fusion of spleen cells with NS-1 myeloma cells using $50 \%$ polyethylene glycol. Hybridomas were selected in hypoxanthine/aminopterin/thymidinesupplemented $L 15$ medium and screened by radioimmunoassay against the surface of living AR4-2J cells. Positive clones were screened by indirect immunofluoresence histochemistry on fresh frozen and fixed sections of rat DRG and spinal cord. Hybridomas secreting antibodies that labeled subpopulations of DRG neurons were cloned three times, by limiting dilution. The carbohydrate specificity of these antibodies was determined by: (i) hemagglutination and radioimmunoassay on a panel of human erythrocytes of known blood group specificity and against rabbit erythrocytes, (ii) radial immunodiffusion assay and solid phase immunoassay against a series of synthetic blood group oligosaccharides (assays were kindly performed by Dr D. Baker, Chembiomed Ltd., Edmonton, Alberta, Canada), and (iii) reactivity with Synsorb $A, B$, and $H$.

The carbohydrate epitope specificity of MAbs KH10, TC6, TD10, LD2, 2C5, and LA4 has been characterized (Table 1). MAb KH10 recognizes carbohydrate structures containing the terminal Gal $\alpha \uparrow-3 \mathrm{Gal} \beta 1-\mathrm{R}$ epitope and reacts strongly with type 1 and 2 human blood group $B$ and linear $B$ determinants (J. Dodd and T. M. Jessell, manuscript in preparation) (Table I). MAb TC6 has a specificity similar to that of MAb KH10. MAb LD2 reacts more strongly with the complete human blood group $B$ trisaccharide than with the Gal $\alpha 1-3 \mathrm{Gal} \beta 1-\mathrm{R}$ epitope but also recognizes the type 2 chain linear 
TABLE I

Fine specificity of MAbs directed against carbohydrate epitopes

\begin{tabular}{|c|c|c|c|}
\hline MAb & Subclass & Carbohydrate Specificity & Reference \\
\hline \multicolumn{4}{|c|}{$\begin{array}{l}\text { 1. Structures based on the type } 1 \\
\text { (GalB1-3GICNAC) lactoseries se- } \\
\text { quence }\end{array}$} \\
\hline FC10.2 & $\lg M$ & $\mathrm{Gal} \beta 1-3 \mathrm{GlcNAc} \beta 1-3 \mathrm{Gal} \beta 1-4 \mathrm{Glc}-\mathrm{R}$ & Gooi et al., 1983 \\
\hline anti-Le ${ }^{a}$ & $\lg M$ & $\begin{array}{c}\text { Gal } \beta 1 \text {-3GlcNAc-R } \\
\mid 1,4 \\
\text { Fuc } \alpha\end{array}$ & $\begin{array}{l}\text { Chembiomed Inc. } \\
\text { Young et al., } 1983\end{array}$ \\
\hline anti-Le ${ }^{b}$ & $\operatorname{lgM}$ & $\begin{array}{l}\text { Gal } \beta 1 \cdot 3 \mathrm{GlcNAc}-\mathrm{R} \\
|1,2 \quad| 1,4 \\
\text { Fuc } \alpha \text { Fuc } \alpha\end{array}$ & Chembiomed inc. \\
\hline $19-9$ & $\lg \mathrm{G} 1$ & $\begin{array}{c}\text { NeuNAC } \alpha 2 \text {-3Gal } \beta 1 \text {-3GicNAc } \beta 1 \text {-3Gal } \beta 1-4 \mathrm{Gic}-\mathrm{R} \\
\qquad \begin{array}{c}\mid 1,4 \\
\text { Fuc } \alpha\end{array}\end{array}$ & Magnani, 1984 \\
\hline \multicolumn{4}{|c|}{$\begin{array}{l}\text { 2. Structures based on the type } 2 \\
\text { (Gal } \beta 1-4 G / C N A C) \text { lactoseries se- } \\
\text { quence }\end{array}$} \\
\hline A5 & $\lg M !$ & Gal $\beta 1-4 \mathrm{GlcNAC-R}$ & Fenderson et al. 1983, \\
\hline $1 \mathrm{~B} 2$ & $\lg M \int$ & & Young et al., 1981 \\
\hline $\mathrm{C} 6$ & $\lg M$ & $\begin{array}{l}\mathrm{Ga} \mid \beta 1-4 \mathrm{GlcNAc} \beta 1-6 \\
\mathrm{Ga} \mid \beta 1-4 \mathrm{GlcNAc} \beta 1-3^{\prime}\end{array}$ & Fenderson et al., 1983 \\
\hline Blood group H (type 2) & $\lg M$ & $\begin{array}{l}\text { Gal } \beta 1-4 \text { GlcNAC-R } \\
\mid 1,2 \\
\text { Fuc } \alpha\end{array}$ & Chembiomed Ltd. \\
\hline Blood group A (type 2) & $\lg M$ & $\begin{array}{c}\text { GalNAC } \alpha 1-3 \mathrm{Ga}|\beta 1-4 \mathrm{G}| \mathrm{cNAC}-\mathrm{R} \\
\mid \begin{array}{c}1,2 \\
\text { Fuc } \alpha\end{array}\end{array}$ & Chembiomed Ltd. ${ }^{a}$ \\
\hline Blood group B (type 2) & $\lg M$ & $\begin{array}{c}\text { Gal } \alpha 1-3 \mathrm{Ga}|\beta 1-4 \mathrm{G}| \mathrm{CNAC}-\mathrm{R} \\
\mid 1,2 \\
\text { Fuc } \alpha\end{array}$ & Chembiomed Ltd. ${ }^{a}$ \\
\hline 2C5 & $\lg M$ & Gal $\alpha 1-3 \mathrm{Gal} / \rho 1-4 \mathrm{Gl}$ CNAC-R & $\begin{array}{l}\text { Randle, } 1982 \\
\text { Jessell and Dodd, } 1985\end{array}$ \\
\hline $\begin{array}{l}\text { KH10, LD2, TC6, TD10 } \\
\text { LA4 }\end{array}$ & $\operatorname{lgM}$ & $\begin{array}{l}\text { Gal } \alpha 1-3 \mathrm{Ga}|\beta 1-4 \mathrm{Gl}| \mathrm{NAC}-\mathrm{R} \\
\text { and }\end{array}$ & Jessell and Dodd, 1985 \\
\hline & & $\begin{array}{l}\text { Gal } \alpha 1-3 \mathrm{Gal} \beta 1-4 \mathrm{Gl} \mathrm{cNAc}-\mathrm{R} \\
\mid 1,2 \\
\text { Fuc } \alpha\end{array}$ & Jessell and Dodd, 1985 \\
\hline anti-SSEA-1 ( $X$ hapten) & $\lg M$ & $\begin{array}{c}\text { Gal } \beta 1-4 \text { GlcNAc-R } \\
\qquad 1,3 \\
\text { Fuc } \alpha\end{array}$ & Gooi et al., 1981 \\
\hline F3, 75.12 (Y hapten) & $\operatorname{lgM}$ & $\begin{array}{l}\text { Gal } \beta 1-4 \text { GlcNAC-R } \\
|1,2 \quad| 1,3 \\
\text { Fuc } \alpha \quad \text { Fuc } \alpha\end{array}$ & $\begin{array}{l}\text { Lloyd et al., } 1983 \\
\text { Blaineau et al., } 1983\end{array}$ \\
\hline $\begin{array}{l}\text { 3. Globoseries structures } \\
\text { anti-Gb3 (38-13) } \\
\text { anti-SSEA-3 } \\
\text { anti-SSEA-4 } \\
\text { anti-Forssman (M1/22.25) }\end{array}$ & $\begin{array}{l}\text { rat } \lg M \\
\text { rat } \lg M \\
\operatorname{lgG} 3 \\
\text { rat } \lg M\end{array}$ & $\begin{array}{l}\text { Gal } \alpha 1-4 \mathrm{Gal} \beta 1-4 \mathrm{Glc} \beta 1 \text {-Cer } \\
\text { GalNAc } \beta 1-3 \mathrm{Gal} \alpha 1-4 \mathrm{Gal} \beta 1-\mathrm{R} \\
\text { NeuAC } \alpha 2-3 \mathrm{Gal} \beta 1-3 \mathrm{GalNAC}-\mathrm{R} \\
\text { GalNAC } \alpha 1-3 \mathrm{GalNAc} \beta 1-3 \mathrm{Gal} \alpha 1-4 \mathrm{Gal} \beta 1-4 \mathrm{G} \mid \mathrm{c} \text {-Cer }\end{array}$ & $\begin{array}{l}\text { Nudelman et al., } 1983 \\
\text { Shovinsky ct al., } 1982 \\
\text { Kannagi et al., } 1983 \mathrm{C} \\
\text { Willison et al., } 1982\end{array}$ \\
\hline
\end{tabular}

${ }^{a}$ These antibodies also recognize type 1 blood group $A$ and $B$ structures.

B structure. MAD TD10 appears to recognize a carbohydrate epitope distinct from that of MAbs KH10, TC6, and LD2. It acts as a blood group B-specific cold agglutinin on human $B$ and rabbit erythrocytes and exhibits a differential specificity on Synsorb A, B, and $\mathrm{H}$. MAb LA4 recognizes an epitope on both the linear and branched $B$ determinants that is closely related but distinct from the epitope recognized by MAbs $\mathrm{KH} 10$ and I D2. MAb $2 \mathrm{C} 5$ recognizes the linear blood group B structure Gal $\alpha 1-3 \mathrm{Gal} / 31-3 / 4 \mathrm{GlcNAC}-\mathrm{R}$ that is present on rabbit erythrocytes (Hanfland et al., 1981) but does not react with the $\alpha(1,2)$-fucosylated human blood group $\mathrm{B}$ determinant. A complete description of the methods of MAb generation and analysis of the carbohydrate specificity of these MAbs will be published elsewhere. Biochemical analysis has demonstrated that the lactoseries carbohydrate antigens are present as neutral and acidic glycosphingolipids on DRG neurons and on AR4-2J cells (J. Dodd, J. L. Magnani, and T. M. Jessell, manuscript in preparation).

Materials. MAbs anti-SSEA-1 (480), anti-SSEA-3 (MC631), and anti-SSEA4 (MC813-70) were provided by Dr. D. Solter, Wistar Institute (Philadelphia,
PA); MAbs A5 and $\mathrm{C} 6$ were provided by Dr. B. Fenderson, Fred Hutchinson Cancer Research Centre (Seattle, WA). MAb 1B2/1B7 was obtained from the American Type Culture Collection (Bethesda, MD) and from Dr. W. W. Young, University of West Virginia (Morgantown). MAb 2C5 was obtained from Accurate Scientific and was also provided by Drs. B. Randle and S. Lawson. University of Bristol, (Bristol, United Kingdom). MAb Y 3 was provided by Dr K. Lloyd, Memorial Sloan Kettering Cancer Center (New York, NY) and MAb 75.12 was provided by Dr. P. Avner, Institute Pasteur (Paris, France). Monoclonal anti-Forssman antibody (M1/22.25) and MAb 38-13 (anti-globotriaosyl ceramide) (Nudelman et al., 1983) were obtained from Dr. K. Willison, Imperial Cancer Research Fund Laboratories (London, United Kingdom). MAbs to Lewis a were provided by Dr. W. Young (MAb CF4C4), by Dr. M. Herlyn (151-6-A7-9), and by Dr. D. Baker (AH7-229A), and MAbs to Lewis b were provided by Dr. M. Herlyn (143-2A6-11) and Dr. D. Baker (AH8-11). MAb 19-9 directed against sialylated Lewis a was provided by Dr. M. Herlyn. MAb FC10.2 was provided by Dr. R. Mclihinney, Ludwig Institute for Cancer 
Research (Sutton, United Kingdom). The carbohydrate structures recognized by these MAbs are shown in Table I.

Rabbit anti-SP and anti-SOM antisera were kindly provided by Dr A. J. Harmar, Medical Research Council Brain Metabolism Unit (Edinburgh, United Kingdom) and was obtained from ImmunoNuclear Inc. (Stillwater, MN).

FITC-goat anti-mouse IgM was obtained from Tago Inc. (Burlingame CA), FITC-goat anti-mouse lgG was obtained from Boehringer Mannheim, Rh-goat anti-mouse IgG was obtained from Tago Inc., and unconjugated rabbit antimouse subclass-specific second antibodies were obtained from Litton Bionetics, MD. Polyethylene glycol-4000 was obtained from Merck Darmstadt (Federal Republic of Germany). Synsorb (A, B, and H) was obtained from Chembiomed Ltd. (Alberta, Canada).

\section{Results}

Expression of lactoseries backbone structures on subsets of $D R G$ neurons. In previous studies we have demonstrated that DRG neurons with projections to laminae III and IV of the dorsal horn express complex globoseries carbohydrates (Dodd et al., 1984; Jessell and Dodd, 1985). Since, during the differentiation of many non-neural cells, the expression of globoseries carbohydrates is accompanied by the appearence of lactoseries structures (Kannagi et al., 1983a; Hakomori, 1984), we examined the possibility that DRG neurons also express lactoseries carbohydrate structures.

We first used MAbs that discriminate between type 1 and type 2 lactoseries backbone sequences (Table I). MAbs A5 (Fenderson et al., 1983) and 1B2/1B7 (Young et al., 1981) are directed against the $N$-acetyl-lactosamine (Gal $\beta 1$-4GlcNAc) backbone unit that forms the basis of type 2 chain lactoseries carbohydrates (Table I; see Fig. 11) (Feizi, 1984). The fine specificity of these two MAbs is similar or identical, and we have not detected any differences in the distribution of sensory neuron antigens recognized by MAbs A5 and 1B2/1B7. In the majority of experiments we have used MAb A5.

The type $2 \mathrm{~N}$-acetyl-lactosamine disaccharide epitope was expressed by a subset of neurons in the adult rat DRG. Approximately 40 to $45 \%$ of DRG neurons were $\mathrm{A}^{+}$, with the majority of labeled neurons confined to the small- and intermediate-diameter populations (Fig. 1a). $\mathrm{A}^{+}$DRG neurons exhibited varying intensities of cytoplasmic labeling, associated with vesicular or granular structures and with the neuronal plasma membrane. The largest $\mathrm{A5}^{+} \mathrm{DRG}$ neurons exhibited prominent surface membrane-associated labeling (Figs. $1 a$ and $2 a$ ), with less intense cytoplasmic staining. About half of the smaller-diameter $\mathrm{A5}^{+} \mathrm{DRG}$ neurons exhibited intense cytoplasmic labeling (Figs. $1 a$ and $2 a$ ), whereas the remaining neurons exhibited weaker cytoplasmic labeling (these neurons were clearly distinguishable from A5- DRG neurons) (Figs. 1a and 2). These three classes of $\mathrm{A5}^{+} \mathrm{DRG}$ neurons were also apparent with MAb $1 \mathrm{~B} 2 / 1 \mathrm{~B} 7$ and were detectable in fresh-frozen and in paraformaldehyde- or Bouin's-fixed sections and, therefore, do not appear to reflect differences in fixation. Since the A5- and 1B2/1B7-reactive
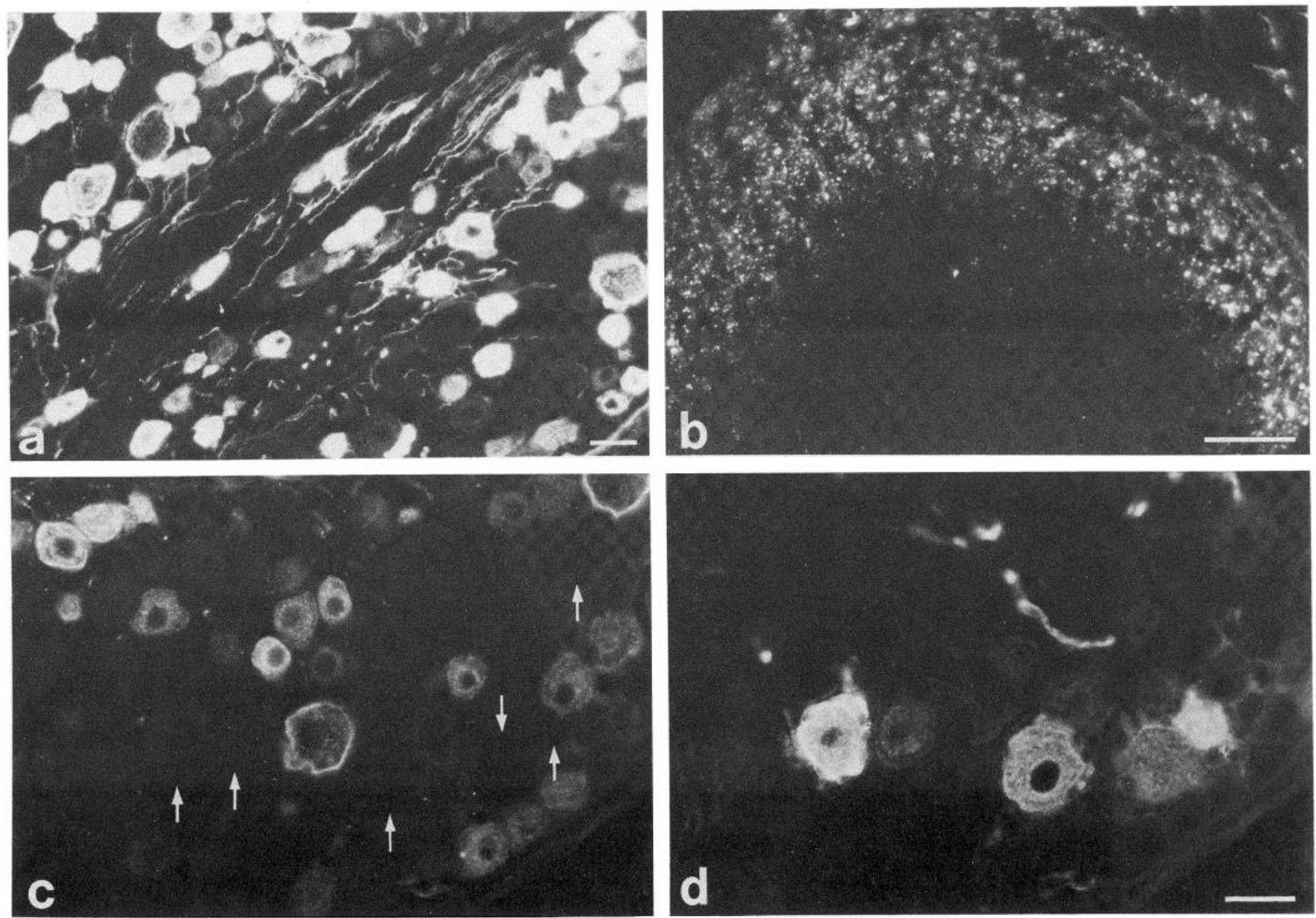

Figure 1. Lactoseries carbohydrates are expressed in the cell bodies and terminals of a distinct subset of DRG neurons. a, A5-immunoreactive neurons

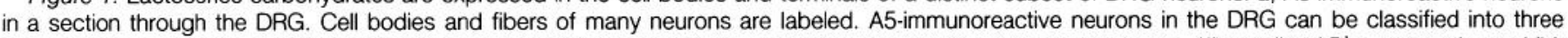

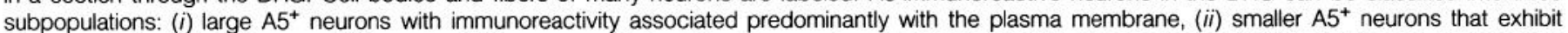

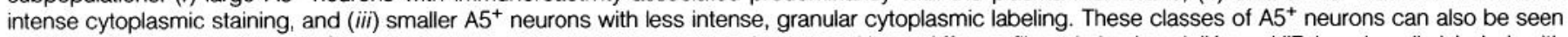

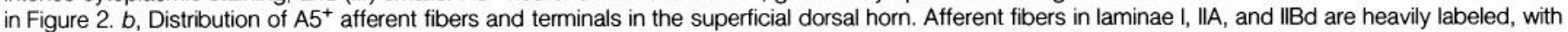

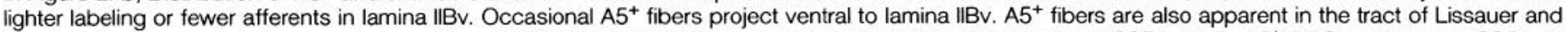

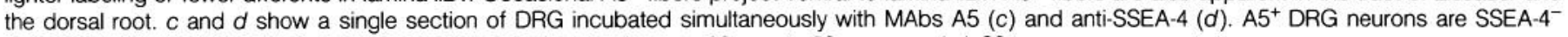
(SSEA-4 $4^{+}$neurons are indicated with arrows in $c$ ). Calibration bars: $a, 20 \mu \mathrm{m} ; b, 50 \mu \mathrm{m} ; c$ and $d, 30 \mu \mathrm{m}$. 
type 2 disaccharide epitope represents the backbone structure of several complex lactoseries carbohydrates (see below and Fig. 11, Table I), differences in intensity of A5 and 1B2/1B7 labeling may reflect the presence of different carbohydrate structures on these three DRG neuronal populations. The type $2 \mathrm{~N}$-acetyl-lactosamine disaccharide epitope is found in both unbranched (i) and branched (I) structures on mammalian cells (Feizi et al., 1971; Fukuda and Fukuda, 1984). DRG neurons appear to express lactoseries structures that more closely resemble the linear (i) antigens since MAb C6, which recognizes a branched type 2 (I) determinant (Fenderson et al., 1983), did not label adult DRG neurons.

$\mathrm{A}^{+}$neurons were present in DRG at cervical, thoracic, lumbar, and sacral levels. Tangential sections through the dorsal roots revealed numerous $\mathrm{A}^{+}$afferent fibers which entered the spinal cord via the tract of Lissauer. A dense plexus of $\mathrm{A}^{+}$afferent fibers and terminals was present within laminae I and IIA and, at decreased density, in lamina $\| B d$ (Figs. $1 b$ and 10). A5 immunoreactivity was absent from the ipsilateral dorsal horn of rats subjected to dorsal rhizotomy 14 days before immunocytochemical analysis, indicating that, in the spinal cord, A5 immunoreactivity is restricted to the processes and terminals of primary sensory neurons. Neurons and non-neuronal cells in supraspinal regions of the CNS did not express detectable levels of A5 immunoreactivity.

DRG neurons with central terminal arbors in laminae III and IV of the dorsal horn express globoseries carbohydrate antigens (Dodd et al., 1984) (see Fig. 10). The segregation of afferent terminals expressing globo- and lactoseries antigens suggested that these two classes of carbohydrates are present on functionally distinct populations of DRG neurons. The relationship between globo- and lactoseries carbohydrate antigens in DRG neurons was therefore examined with MAb anti-SSEA-4 (mouse lgG3) and MAb A5 (mouse IgM). There was virtually no overlap $\left(<0.1 \%\right.$ of SSEA- $4^{+}$neurons were $\mathrm{A}^{+}$) between SSEA-4 $4^{+}$and $\mathrm{A} 5^{+}$DRG neurons (Fig. 1, $\mathrm{c}$ and d). Since MAb anti-SSEA-3 is an IgM, experiments with directly labeled MAbs will be necessary to determine the relationship between SSEA $-3^{+}$and $\mathrm{A}^{+}$terminals in lamina I.

Separate populations of small-diameter DRG neurons with projections to the superficial dorsal horn are known to contain the peptides SP and SOM and the enzyme FRAP (Hokfelt et al., 1976; Nagy and Hunt, 1982). We therefore examined the relationship between $\mathrm{A5}^{+}$, $\mathrm{SP}^{+}$, and $\mathrm{SOM}^{+}$DRG neurons. A high proportion of $\mathrm{SP}^{+}(\sim 50 \%)$ and $\mathrm{SOM}^{+}(\sim 80 \%)$ DRG neurons were $\mathrm{A}^{+}$(Fig. 2, Table II). Of the three classes of $\mathrm{A}^{+} \mathrm{DRG}$ neurons described above, larger $\mathrm{A}^{+}$ neurons with prominent membrane labeling were rarely $\mathrm{SP}^{+}$or $\mathrm{SOM}^{+}$. The $\mathrm{A}^{+} / \mathrm{SP}^{+} \mathrm{DRG}$ neurons were usually those that exhibited intense $\mathrm{A}^{+}$cytoplasmic staining, whereas the $\mathrm{A}^{+} / \mathrm{SOM}^{+}$neurons almost invariably exhibited weaker A5 cytoplasmic staining (Fig. 2, a to d). About $60 \%$ of $\mathrm{A}^{+}$neurons were also $\mathrm{FRAP}^{+}$(Table II).

To determine whether DRG neurons also express type $1(\mathrm{Gal} \beta 1$. 3GlcNAc-R) carbohydrate chains, we used MAb FC10.2, directed against an extended type 1 determinant (Table I) (Gooi et al., 1983). About 5 to $10 \%$ of small-diameter DRG neurons expressed the
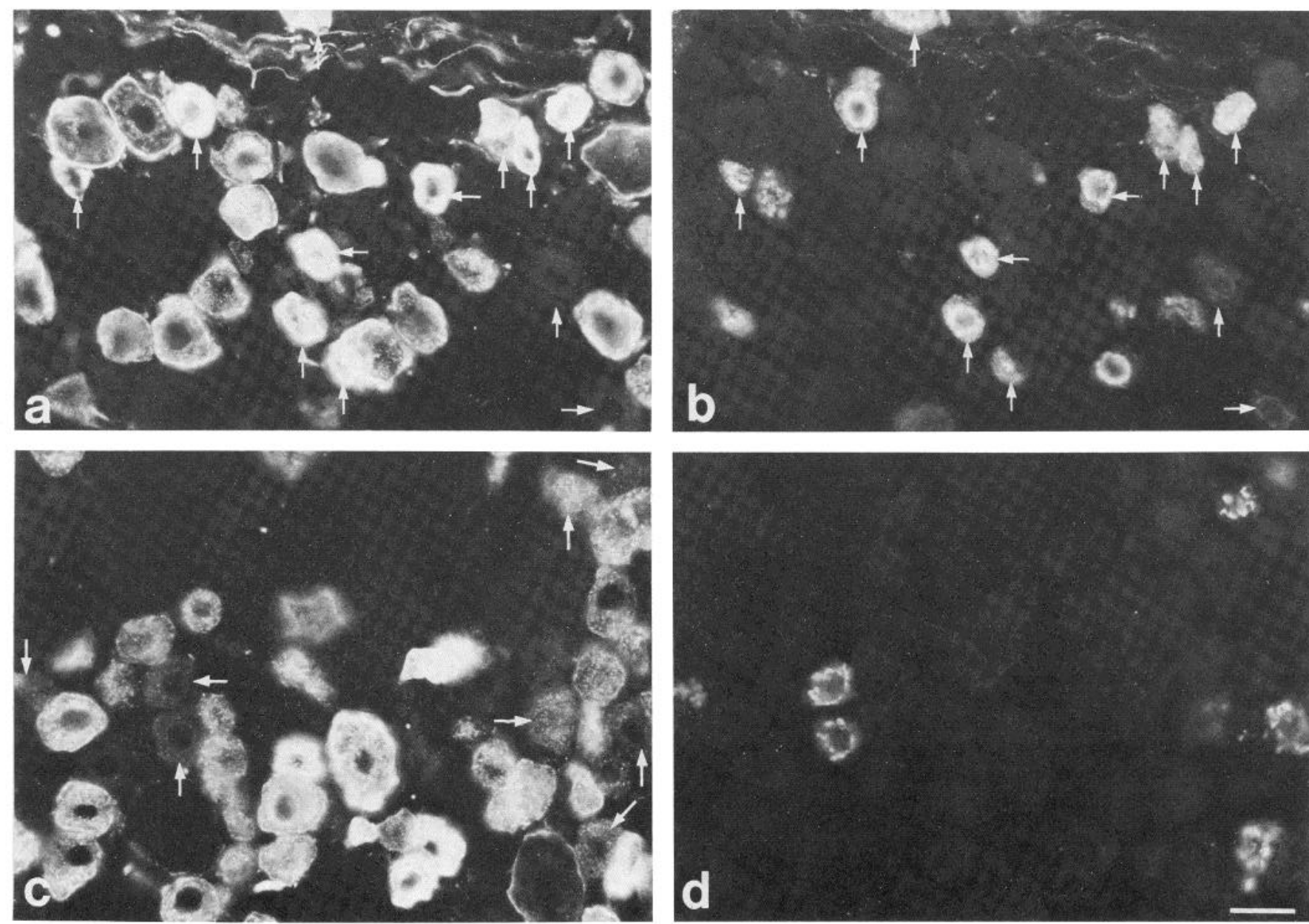

Figure 2. The $\mathrm{N}$-acetyl-lactosamine backbone carbohydrate epitope is expressed by $\mathrm{SP}^{+}$and $\mathrm{SOM}^{+} \mathrm{DRG}$ neurons. $a$ and $b, \mathrm{~A}$ single DRG section incubated with MAb A5 (a) and rabbit anti-SP antiserum (b). Twelve of $19 \mathrm{SP}^{+} \mathrm{DRG}$ neurons in this field are $\mathrm{A5}^{+}$(indicated by arrows in both micrographs). $\mathrm{A}^{+} / \mathrm{SP}^{+} \mathrm{DRG}$ neurons usually exhibit intense A5 cytoplasmic immunoreactivity. $c$ and $d, \mathrm{~A}^{+}(c)$ and $\mathrm{SOM}^{+}(d)$ neurons in a separate $\mathrm{DRG}$ section. $\mathrm{All}$ $\mathrm{SOM}^{+} \mathrm{DRG}$ neurons are $\mathrm{A}^{+}$(indicated by arrows in $\mathrm{c}$ ). $\mathrm{A}^{+} / \mathrm{SOM}^{+}$neurons belong to the lightly stained subset of $\mathrm{A}^{+} \mathrm{DRG}$ neurons described in Figure 3 . Calibration bar, $20 \mu \mathrm{m}$. 
FC10.2 epitope although the intensity of labeling was very weak in comparison to labeling obtained with MAbs A5 or $1 B 2 / 1 B 7$. Since MAbs A5, 1B2/1B7, and FC10.2 are all mouse lgMs, the relationship between DRG neurons expressing type 1 and type 2 lactoseries determinants has not been determined directly. The weak labeling of DRG neuronal cell bodies with MAb FC10.2 also precluded any comparison of the expression of type 1 lactoseries and globoseries carbohydrates, and the relationship of neuronal cell bodies expressing type 1 chains with $\mathrm{SP}^{+}, \mathrm{SOM}^{+}$, and $\mathrm{FRAP}^{+}$DRG neurons. The type 1 epitope recognized by MAb FC10.2 was detectable in fibers and terminals in laminae I, II, and X (surrounding the central canal). Many of the $\mathrm{FC} 10.2^{+}$fibers in the dorsal horn and in lamina $X$ expressed SP immunoreactivity. No FC10.2 immunoreactivity was detectable in the ventral horn of the spinal cord. These observations suggest that some DRG neurons express type 1 lactoseries determinants, although the abundance of these structures appears to be very much less than that of type 2 structures. Alternatively, the type 1 backbone structure may be extensively substituted by saccharides that reduce or abolish FC10.2 immunoreactivity.

TABLE ॥

Summary of relationship between DRG neuron cytoplasmic markers and carbohydrate differentiation antigens

A. Percentage of $\mathrm{SP}^{+}, \mathrm{SOM}^{+}$, and FRAP+ DRG neururls that express carbulydrate antigens identified by monoclonal antibodies

\begin{tabular}{lcccrc} 
& SSEA-3/4 & A5 & KH10/l D2 & LA4 & Lewis a \\
\hline SP & 0 & 50 & 0 & 0 & 10 \\
SOM & 0 & 80 & 100 & 100 & 0 \\
FRAP & 0 & 60 & 15 & $>90$ & 10 \\
\hline
\end{tabular}

B. Percentage of DRG neurons, defined by carbohydrate antigens, that express SP, SOM, and FRAP

\begin{tabular}{lrrr} 
& SP & SOM & FRAP \\
\hline SSEA-3/4 & 0 & 0 & 0 \\
A5 & 20 & 12 & 60 \\
KH10/LD2 & 0 & 30 & 30 \\
LA4 & 0 & 15 & $>75$ \\
Lewis a & 10 & 0 & 90 \\
\hline
\end{tabular}

Complex lactoseries carbohydrates distinguish SP-, SOM-, and FRAP-containing DRG neurons. The type 1 and 2 disaccharide epitopes recognized by MAbs A5, 1B2/1B7, and FC10.2 represent common backbone sequences from which complex lactoseries structures found on a wide variety of mammalian cell types are derived (Feizi, 1984). We therefore used MAbs directed against epitopes on complex lactoseries carbohydrates to identify antigens that might be restricted to functional subsets of small DRG neurons contained within the total $\mathrm{A5}^{+}$population.

MAbs KH10, LD2, TD10, and TC6 recognize galactose $\alpha(1,3)$ extended $\mathrm{N}$-acetyl-lactosamine structures (Table l). Although we have shown the fine epitope specificity of each of these antibodies to be different, all four MAbs labeled a similar or identical subpopulation of neurons in adult rat DRG. The distribution of antigens recognized by MAbs $\mathrm{KH} 10$ and LD2 will be presented here. The carbohydrate structures recognized by MAbs KH10 and LD2 are restricted to primary sensory neurons and were not detectable in adult sympathetic or parasympathetic neurons or in CNS neurons.

About $25 \%$ of DRG neurons, predominantly of small and intermediate diameter, were labeled by each antibody (Table III). MAbs $\mathrm{KH} 10$ and LD2 labeled sensory fibers in the dorsal roots and primary atferent fibers and terminals that were present as a dense band coincident with laminae $\| A$ and $\| B d$ (Figs. $3 b$ and 10). A few $\mathrm{KH}^{+}$ and $\mathrm{LD}^{+}$fibers projected to deeper laminae in the dorsal horn, although the incidence of such fibers was low. No immunoreactivity was observed in the ipsilateral dorsal horn of animals that had been subjected to a unilateral dorsal rhizotomy 14 days before immunocytochemical analysis (Fig. 3,c and $d$ ), indicating that labeling in the dorsal horn is confined to primary afferents.

There was a striking correlation between the expression of lactoseries carbohydrates recognized by MAbs KH10 and LD2 and the neuropeptide phenotype of small DRG neurons. All of the $\mathrm{SOM}^{+}$but none of the $\mathrm{SP}^{+}$DRG neurons expressed the $\mathrm{KH} 10$ and LD2 antigens (Fig. 4, Table II). Colchicine treatment did not increase the number of $\mathrm{SP}^{+}$or $\mathrm{SOM}^{+}$neurons detected in rat DRG and did not alter the relationship between lactoseries carbohydrate and peptide antigens in DRG neurons. SOM ${ }^{+}$neurons cor istituted about $30 \%$ of the total population of DRG neurons labeled with MAbs $\mathrm{KH} 10$ and LD2. About $20 \%$ of $\mathrm{KH}_{10} 0^{+} / \mathrm{LD2}^{+}$DRG neurons were $\mathrm{FRAP}^{+}$. Since

TABLE III

Expression of carbohydrate differentiation antigens by restricted DRG neuronal populations

\begin{tabular}{|c|c|c|c|c|c|c|}
\hline MAb & Carbohydrate Epitope & $\begin{array}{c}\text { Percentage of } \\
\text { DRG Neurons } \\
\text { Labeled }\end{array}$ & $\begin{array}{l}\text { Neuronal } \\
\text { Diameter }^{a}\end{array}$ & & Other Markers & \\
\hline $\begin{array}{l}\mathrm{A} 5 \\
1 \mathrm{~B} 2 / 1 \mathrm{~B} 7\end{array}$ & Gal $\beta 1-4 \mathrm{GlcNAc-R}$ & $40-45$ & $S, 1$ & $\mathrm{SP}$ & SOM & FRAP \\
\hline $\mathrm{FC} 10.2$ & Gal $\beta 1-3 G i c N A c \beta 1-3 G a l \beta 1-4 G \mid c-R$ & $5-10$ & $S$ & $\mathrm{SP}$ & & \\
\hline $\begin{array}{l}\text { LD2 } \\
\text { KH10 } \\
\text { TC6 } \\
\text { TD10 }\end{array}$ & Gal $\alpha 1-3 \mathrm{Gal} \beta 1-4 \mathrm{GlcNAC-R^{ \prime b }}$ & $20-25$ & S & & SOM & FRAP \\
\hline $2 \mathrm{C} 5$ & Gäl $\alpha 1-3$ Gal $\beta 1-4$ GlcNAC-R ${ }^{b}$ & $20-25$ & $S$ & & SOM & FRAP \\
\hline LA4 & Gal $\alpha 1-3 \mathrm{Gal} \beta 1-4 \mathrm{GlcNAC}-\mathrm{R}^{\prime \prime b}$ & $45-50$ & S,I & & SOM & FRAP \\
\hline $\begin{array}{l}\text { AH7-229A } \\
(\alpha \text {-Lewis a) }\end{array}$ & $\mathrm{Ga} \mid \beta 1-3($ Fuc $\alpha 1-4) \mathrm{GicNAC}-\mathrm{R}$ & 20 & $S$ & $\mathrm{SP}$ & & FRAP \\
\hline $\begin{array}{l}480 \\
(\alpha \text {-SSEA-1) }\end{array}$ & Gal $\beta 1-4($ Fuc $\alpha 1-3)$ GlcNAc-R & $<0.1$ & $S$ & & & \\
\hline
\end{tabular}

a $\mathrm{S}, \mathrm{I}$, and L signify small-, intermediate-, or large-diameter DRG neurons.

${ }^{b}$ The structural difference in carbohydrate epitopes recognized by MAbs LD2, KH10, TC6, TD10, by MA6 LA4 and by MAb $2 \mathrm{C5}$, here designated by $R$, $R^{\prime}$ and $R^{\prime \prime}$, is under investigation. 

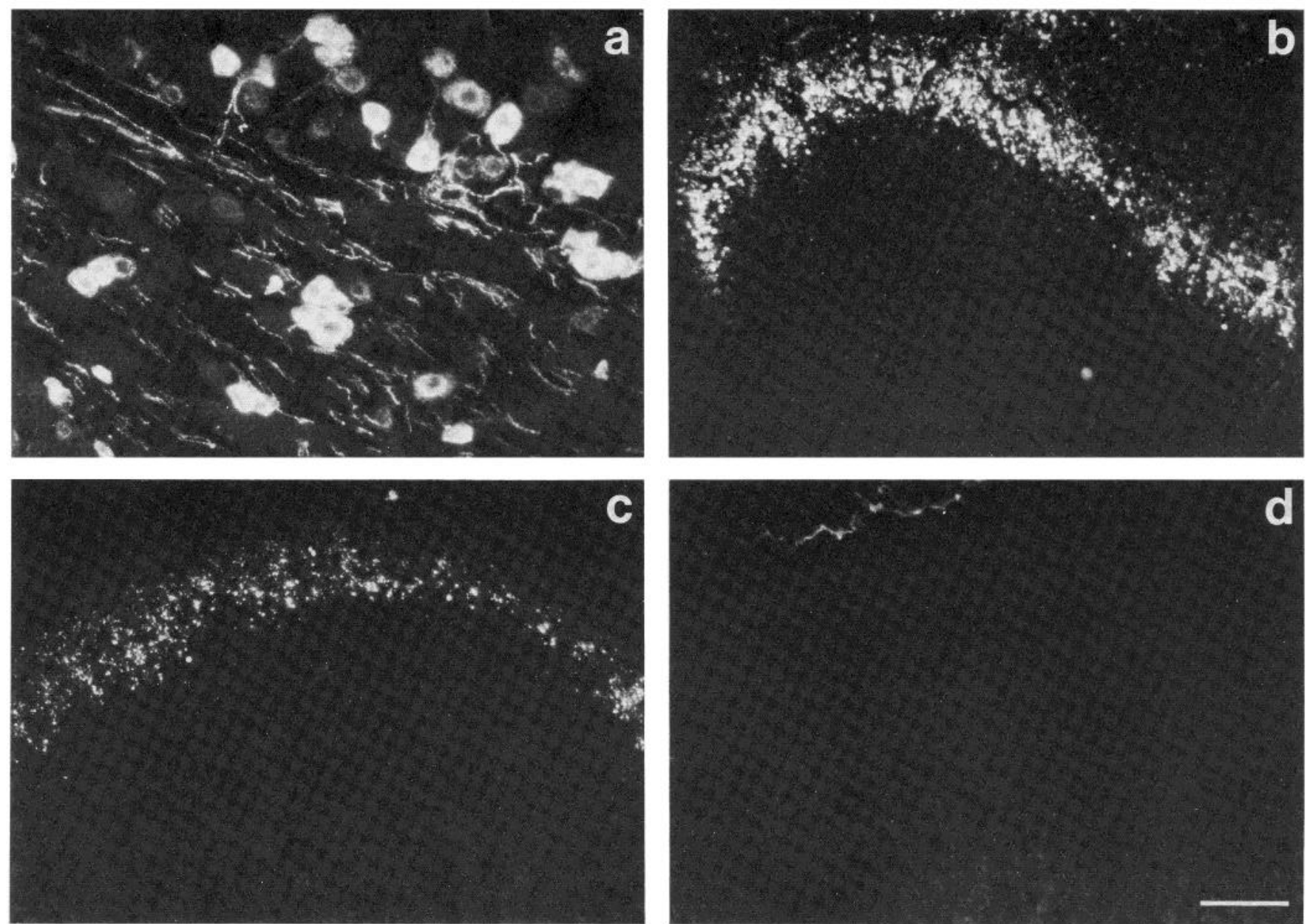

Figure 3. A subset of rat DRG neurons expresses $\alpha 1$,3-galactosyl-extended lactoseries carbohydrates. a, A section of DRG shows LD2 immunoreactivity in a subset of neuronal cell bodies and fibers. $b, L D 2^{+}$fibers and terminals are present at high density in lamina IIBd and at lower density in lamina $\| A$, with a few fibers projecting ventrally. LD2 ${ }^{+}$fibers are also present in the tract of Lissauer. $c$ and $d$, Absence of $\mathrm{KH} 10^{+}$fibers in the dorsal horn after dorsal rhizotomy. Fourteen days after unilateral rhizotomy, $\mathrm{KH}^{+} \mathrm{O}^{+}$fibers and terminals were present in lamina II contralateral to the operation (c) but absent from the ipsilateral dorsal horn (d). Calibration bars: $a, 40 \mu \mathrm{m} ; b, 20 \mu \mathrm{m} ; c, 15 \mu \mathrm{m} ; d, 15 \mu \mathrm{m}$.

there are few, if any, $\mathrm{SOM}^{+} / \mathrm{FRAP}^{+}$neurons in rat DRG (Nagy and Hunt, 1982; Dodd et al., 1983b), it seems likely that $\mathrm{KH}_{10}^{+}, \mathrm{LD}^{+} /$ $\mathrm{FRAP}^{+}$DRG neurons correspond to the $\mathrm{KH}_{10}{ }^{+}, \mathrm{LD}^{+} / \mathrm{SOM}^{-}$population. Moreover, since 45 to $50 \%$ of DRG neurons are $\mathrm{FRAP}^{+}$, our results indicate that carbohydrate antigens recognized by MAbs $\mathrm{KH} 10$ and LD2 must be expressed by a subset of FRAP ${ }^{+}$DRG neurons.

The relationship of $\mathrm{KH}^{+} 0^{+} / \mathrm{LD}^{+} \mathrm{DRG}$ neurons to the population of DRG neurons labeled by MAb 2C5 was also examined. MAb 2C5 was generated by Randle (1982) against an unidentified cell surface antigen on PC-13 embryonal carcinoma cells and has been reported to label a subpopulation of small-diameter DRG neurons (Coackham et al., 1982). The same determinant is found as a developmentally regulated embryonic antigen on preimplantation murine embryos (Randle, 1982). PC-13 cells have been shown previously to express lactoseries carbohydrate structures that are associated with branched polylactosaminoglycans (Renkonen, 1983), and we have identified the epitope recognized by MAb $2 \mathrm{C} 5$ as a linear B-reactive carbohydrate (Table I). As originally reported by Coackham et al. (1982), we found that MAb 2C5 labeled a subset of small-diameter DRG neurons with a specificity similar to that of MAbs $\mathrm{KH} 10$ and LD2 (Table III).

Evidence for a differential distribution of complex lactoseries oligosaccharides on subsets of small-diameter DRG neurons was obtained with MAb LA4. Although MAb LA4 also recognizes a linear B-related carbohydrate structure (Table I), confirmation of a distinct epitope specificity of MAbs LA4 and KH10/LD2 was obtained by examining the distribution of the LA4 epitope in adult rat DRG neurons. The LA4 epitope was expressed by 45 to $50 \%$ of DRG neurons, predominantly of small and intermediate diameter (Fig. 5a, Table III). In contrast to the intense granular cytoplasmic immunoreactivity detected with other anti-lactoseries antibodies, LA4 immunoreactivity was associated predominantly with perinuclear Golgi apparatus and with the neuronal plasma membrane (Fig. 5a). The LA4 antigen is also restricted to primary sensory neurons and appears to be absent from spinal cord neurons. Within the spinal cord, $\mathrm{LA}_{4}{ }^{+}$afferent fibers and terminals were located predominantly within lamina $\| \mathrm{BV}$ with fiber and terminal labeling also apparent at lower density, in lamina IIBd (Figs. $5 b$ and 10). There was no overlap between $\mathrm{LA}^{+}$and SSEA-4 ${ }^{+} \mathrm{DRG}$ neurons. There was also no overlap between $\mathrm{LA}^{+}$and $\mathrm{SP}^{+} \mathrm{DRG}$ neurons. All $\mathrm{SOM}^{+} \mathrm{DRG}$ neurons were $\mathrm{LA}_{4}^{+}$, although the intensity of LA4 immunoreactivity in these neurons was lower than in the $\mathrm{LA4}^{+} / \mathrm{SOM}^{-}$population. In distinction to MAbs $\mathrm{KH} 10$ and LD2, however, LA4 labeled greater than $90 \%$ of the FRAP $^{+}$DRG neurons and, conversely, FRAP $^{+}$ neurons constituted greater than $75 \%$ of $\mathrm{LA4}^{+}$neurons (Fig. $5, \mathrm{C}$ to $f$; Table II). Since it was technically difficult to combine the indirect immunofluorescence localization of the LA4 antigen with enzyme histochemical localization of FRAP, the overlap between $\mathrm{LA4}^{+}$and FRAP $^{+}$DRG neurons may be more extensive than these numbers indicate. These results provide evidence that MAb LA4 identifies a carbohydrate determinant that is structurally related to, but distinct 

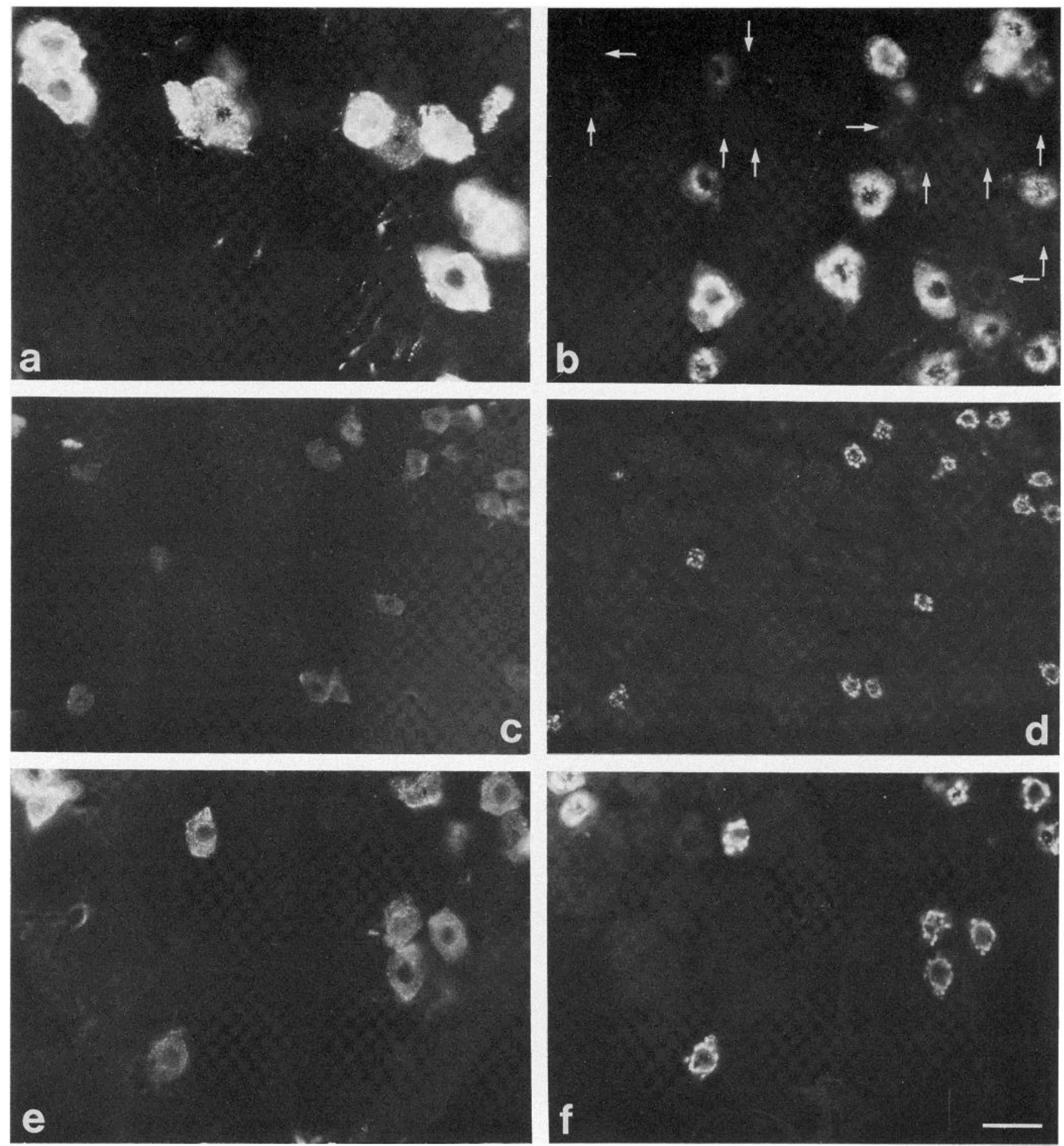

Figure 4. $\mathrm{SOM}^{+}$but not $\mathrm{SP}^{+} \mathrm{DRG}$ neurons are $\mathrm{KH}^{+} 0^{+} / \mathrm{LD}^{+}$. $a$ and $b, \mathrm{~A}$ single DRG section incubated with MAb KH10 (a) and rabbit anti-SP antiserum (b). The location of $\mathrm{KH}_{1} 0^{+} \mathrm{DRG}$ neurons is indicated with arrows in $b$. No $\mathrm{SP}^{+}$neurons are $\mathrm{KH} 10^{+} . c$ and $d$ show a single section of DRG incubated with $\mathrm{MAb} \mathrm{KH10}(c)$ and rabbit anti-SOM antisera (d). All SOM ${ }^{+}$neurons are $\mathrm{KH}_{10}{ }^{+}$. $e$ and $f, \mathrm{All} \mathrm{SOM}^{+}$neurons ( $f$ ) are LD2 ${ }^{+}(e)$. Calibration bar: $a$ and $b, 20 \mu \mathrm{m}$; $c$ and $d, 35 \mu \mathrm{m} ; e$ and $f, 25 \mu \mathrm{m}$.

from, the LD2 epitope. Since the LD2 and LA4 determinants are closely related, it is possible that the weak labeling of $\mathrm{SOM}^{+} \mathrm{DRG}$ neurons by MAb LA4 reflects the ability of MAb LA4 to react with more than one carbohydrate antigen on DRG neurons. Alternatively, $\mathrm{SOM}^{+} \mathrm{DRG}$ neurons may express two structurally related oligosaccharides, one reactive with MAbs $\mathrm{KH} 10$ and LD2, and the other with MAb LA4.

The observation that $\mathrm{SP}^{+}$fibers in the dorsal horn expressed the type 1 lactoseries antigen recognized by MAb FC10.2 suggested that MAbs directed against complex type 1-derived carbohydrate structures might also be associated with $\mathrm{SP}^{+} \mathrm{DRG}$ neurons. In support of this, expression of the Lewis a determinant (Table I) by $\mathrm{SP}^{+}, \mathrm{SOM}^{+}$, and $\mathrm{FRAP}^{+} \mathrm{DRG}$ neurons was strikingly different from that of the complex type 2 structures recognized by MAbs $\mathrm{KH} 10$, LD2, and LA4. The Lewis a determinant, recognized by MAb AH7$229 \mathrm{~A}$, was present in the cytoplasm of a subset $(\sim 20 \%)$ of small- 

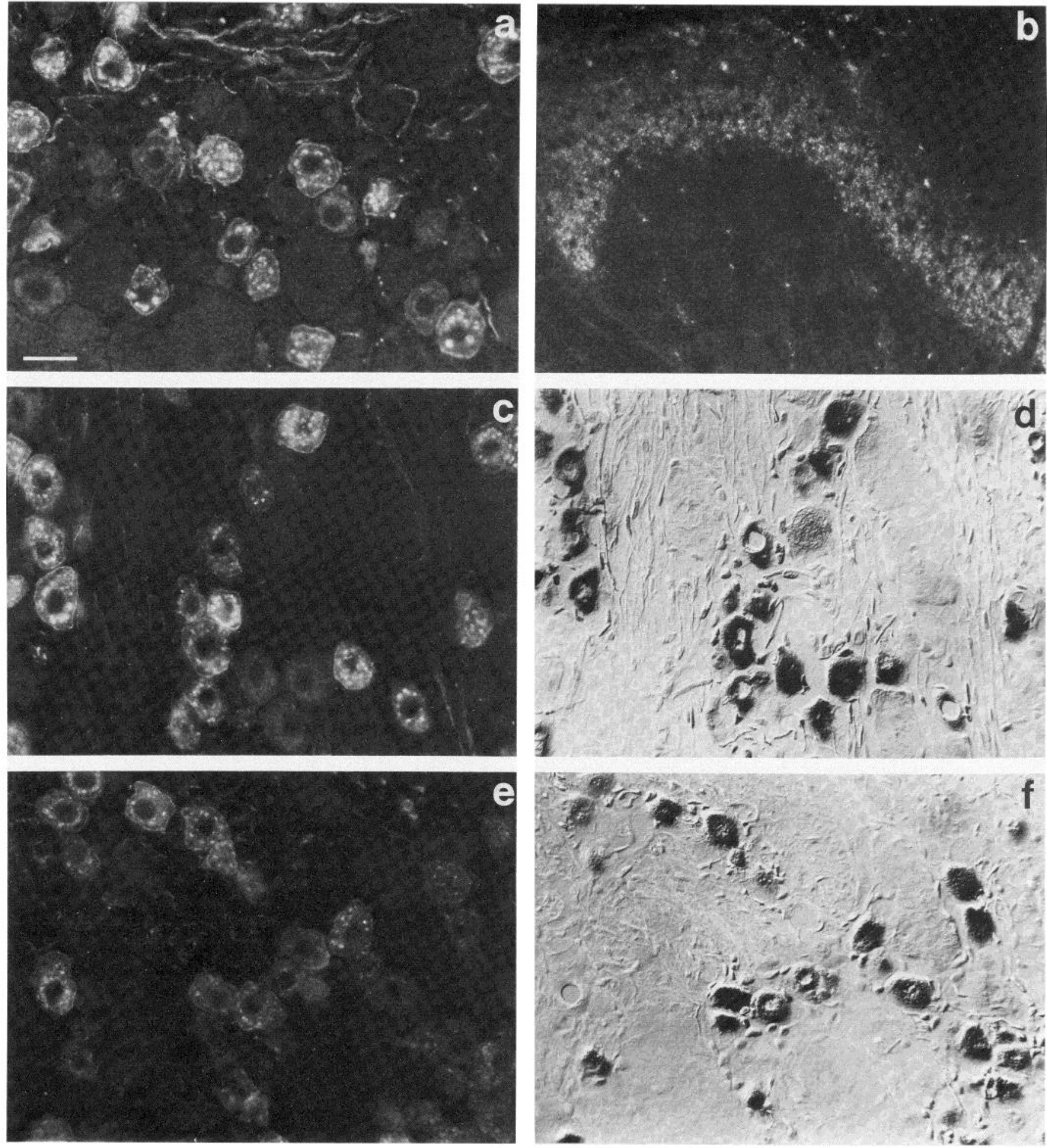

Figure 5. MAb LA4 labels the cell bodies and terminals of a distinct population of DRG neurons. $a, L_{1} 4^{+}$neurons in a section of DRG. Immunoreactivity is associated with both the plasma membrane and the cytoplasm, with prominent labeling of perinuclear structures. $b$, The central terminals of LA4 ${ }^{+}$DRG neurons are found in a dense band in lamina IBV of the dorsal horn. Less intense LA4 immunoreactivity is present in lamina IBd. $c$ and $e$, LA4 ${ }^{+}$DRG neurons in two separate sections of DRG. $d$ and $f$ show the localization of enzyme reaction product in the same two sections after subsequent histochemical processing with a selective substrate for the FRAP isoenzyme. In each section, almost all FRAP ${ }^{+}$neurons are LA4 ${ }^{+}$and many of the LA4 ${ }^{+}$neurons are FRAP $^{+}$. (Note that dehydration of the sections following acid phosphatase histochemistry causes some tissue shrinkage.) Calibration bar: $a, c, d, e$, and $f$, $25 \mu \mathrm{m} ; b, 30 \mu \mathrm{m}$.

diameter DRG neurons (Fig. 11a, Table III). About $10 \%$ of Lewis $\mathrm{a}^{+}$ neurons were $\mathrm{SP}^{+}$(Fig. 6, $a$ and $b$ ), whereas there was no overlap between Lewis $\mathrm{a}^{+}$and $\mathrm{SOM}^{+}$DRG neurons (Fig. 6, $c$ and $d$ ) (Table II). Between 80 and $90 \%$ of Lewis $\mathrm{a}^{+}$DRG neurons were $\mathrm{FRAP}^{+}$. In the spinal cord, Lewis a immunoreactivity was present at low levels throughout the dorsal and ventral horns, although a more intense band of immunoreactive fibers was detected in laminae I and II of the dorsal horn. 

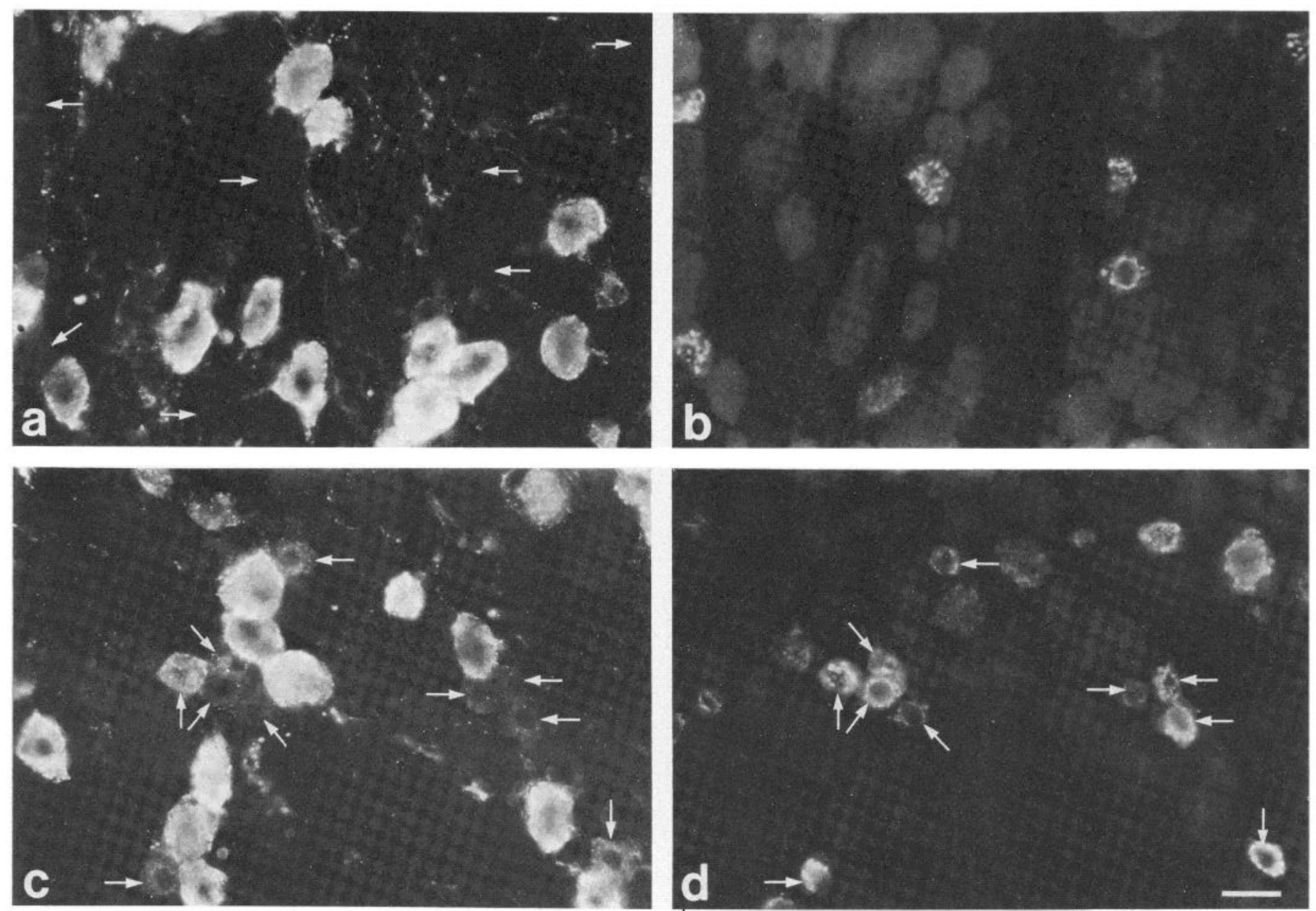

Figure 6. Expression of the Lewis a carbohydrate structure by a subset of DRG neurons. a, Immunocytochemical localization of the Lewis a antigen in a subpopulation of small- and intermediate-diameter DRG neurons. $b$, Localization of SOM-immunoreactive DRG neurons in the same section. No Lewis a ${ }^{+}$ neurons are $\mathrm{SOM}^{+} . c$ and $d$, Dual immunofluorescence localization of Lewis a antigen $(c)$ and $\mathrm{SP}(d)$ on a single DRG section. About $10 \%$ of labeled neurons are Lewis $\mathrm{a}^{+} / \mathrm{SP}^{+}$. Calibration bar, $30 \mu \mathrm{m}$.

We screened several other MAbs that recognize fucosylated or $\mathrm{N}$-acetylgalactosamine-extended lactoseries carbohydrates (Table I). With the exception of SSEA-1, which we have previously shown to be present in $<0.1 \%$ of adult DRG neurons (Jessell and Dodd, 1985), none of these structures were expressed by rat DRG neurons.

Expression of lactoseries carbohydrate antigens by cranial sensory ganglia. In order to examine whether lactoseries carbohydrates are restricted to sensory neurons that derive from the neural crest, we analyzed the distribution of these antigens in cranial sensory ganglia. There was a striking segregation in the distribution of globoand lactoseries antigens between ganglia of placodal and neural crest origin. The SSEA-3 and SSEA-4 globoseries carbohydrate antigens were present in more than $90 \%$ of neurons in the nodose ganglion, which are thought to derive from placodal structures, whereas less than $10 \%$ of neurons in the neural crest-derived jugular ganglion were SSEA $-3^{+}$or SSEA $-4^{+}$(Fig. $7, a$ and $b$ ). In contrast, the lactoseries antigens recognized by MAbs A5, KH10, LD2, and LA4 were present in $<2 \%$ of sensory neurons in the nodose ganglion but were present in 30 to $50 \%$ of neurons in the jugular ganglion (Fig. 7, $c$ to $f$ ).

Expression of lactoseries carbohydrate antigens on the surface of DRG neurons. To examine whether lactoseries carbohydrates are expressed on the surface of sensory neurons, DRG neurons obtained from 0 to 2-day postnatal rats were grown in dissociated cell culture for periods of 10 to 28 days. Approximately $20 \%$ of DRG neurons maintained in culture for 10 days expressed the A5 antigen, with immunoreactivity clearly associated with the cell bodies and processes of DRG neurons (Fig. 8, $a$ and $b$ ). Schwann cells and the majority of other non-neuronal cells in the cultures were not labeled by MAb A5. Occasional large, flat cells did express the A5 antigen on the surface. However, the origin of these cells has not been investigated. Some, but not all of the complex lactoseries carbohydrate antigens were expressed on the surface of cultured DRG neurons. Fewer than $10 \%$ of cultured DRG neurons were labeled with MAbs $\mathrm{KH} 10$ and LD2 (Fig. 8, $c$ and $d$ ). MAb KH10- and LD2reactive carbohydrates were present on the cell bodies and processes of labeled DRG neurons with no staining of non-neuronal cells in the cultures. In contrast, MAb $2 \mathrm{C5}$ did not label the surface of cultured DRG neurons. MAb LA4 labeled the surface of about $20 \%$ of DRG neurons in culture, with labeling of both cell bodies and processes (Fig. 8, e and f). LA4 ${ }^{+}$DRG neurons appeared to be more intensely labeled than DRG neurons incubated, under identical conditions, with other anit-lactoseries MAbs.

These studies establish that lactoseries carbohydrates are expressed on the surface of subsets of DRG neurons. The proportion of cultured DRG neurons labeled with MAbs directed against lactoseries structures was consistently lower than the number of neurons labeled by the same MAbs in sections of DRG from adult rats. Although the FC10.2 and Lewis a determinants were present in subsets of adult DRG neurons, they were not detected on the surface of cultured DRG neurons. In addition, the Lewis b-, $\mathrm{Y}_{-}$, and 19-9-reactive structures were not detected on the surface of cultured DRG neurons.

The segregation of cultured DRG neurons expressing globoseries 

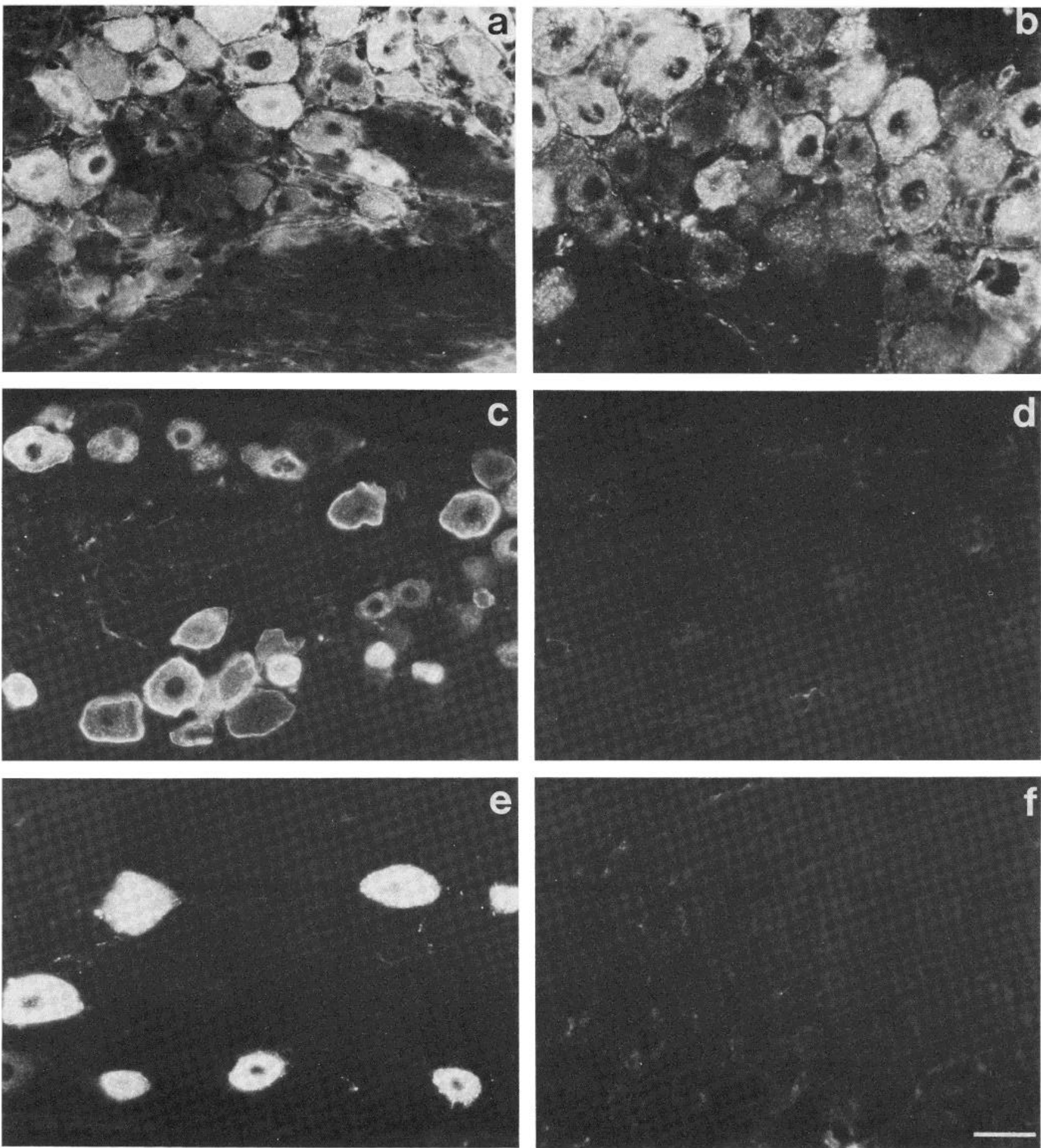

Figure 7. Globo- and lactoseries carbohydrates are expressed by subsets of cranial sensory neurons. $a$ and $b$, Cryostat sections of the rat nodose ganglion labeled with MAbs anti-SSEA-3 and anti-SSEA-4. The vast majority of neurons in the nodose ganglion are labeled with both antibodies. $c$ and $d$, $\mathrm{A}^{+}$neurons are present in the jugular ganglion (c). Very few neurons in the nodose ganglion are labeled with $\mathrm{MAb} \mathrm{A} 5(d)$. e and $t, \mathrm{KH} 10^{+}$neurons in the jugular ganglion (e). No KH10 neurons were detected in the nodose ganglion ( $f$ ). Calibration bar: $a, 25 \mu \mathrm{m} ; b, 20 \mu \mathrm{m} ; c$ to $f, 30 \mu \mathrm{m}$.

and lactoseries antigens was also examined. Less than $1 \%$ of SSEA$4^{+}$DRG neurons in culture were $\mathrm{A}^{+}, \mathrm{LD}^{+}, \mathrm{LA}^{+}$; or SSEA $-1^{+}(\mathrm{Fig}$ $9, a$ to $f$ ). The relationship between the expression of globo- and lactoseries determinants on the surface of DRG neurons in culture therefore mimicks that observed in the cytoplasm of DRG neurons in situ.

\section{Discussion}

The present results provide further evidence that functional subsets of DRG neurons with restricted central terminal domains in the dorsal horn of the spinal cord express unique carbohydrate phenotypes. The central terminals of afferent fibers that express globo- 

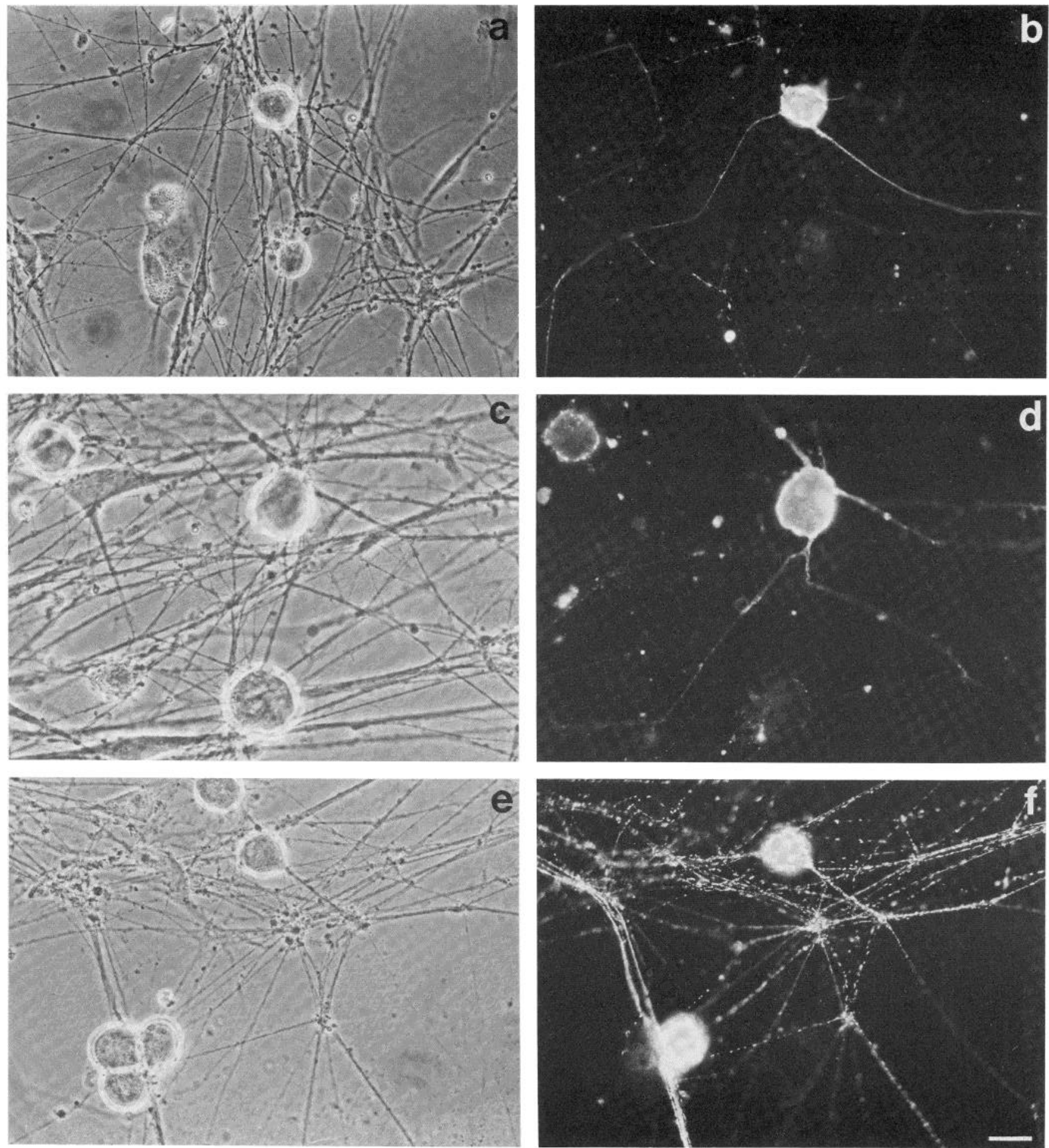

Figure 8. Expression of lactoseries carbohydrates on the surface of cultured DRG neurons. $a, c$, and $e$, Phase contrast micrographs of cultured DRG neurons. $b, d$, and $f$, Surface labeling of subsets of these neurons by MAbs A5, LD2, and LA4, respectively. Note the intense labeling of both cell bodies and processes. Calibration bar: $a$ and $b, 20 \mu \mathrm{m} ; c$ and $d, 20 \mu \mathrm{m} ; e$ and $f, 15 \mu \mathrm{m}$.

series determinants are distributed sparsely within lamina I and as a dense plexus within laminae III and IV (Dodd et al., 1984), whereas the present findings demonstrate that lactoseries immunoreactive afferent terminals are present throughout laminae I and II but are virtually absent from regions ventral to lamina II.

Comparison of the spinal cord distribution of carbohydrate antigens with the termination sites of different classes of cutaneous afferent fibers in rodents (Nagy and Hunt, 1983), cats, and primates (Brown, 1981; Perl, 1983) suggests that globoseries determinants may be restricted to myelinated primary afferents and lactoseries determinants to unmyelinated fibers. Thinly myelinated fibers conveying thermoreceptive and high threshold mechanoreceptive information are known to terminate within lamina I (Perl, 1983). Many classes of rapidly conducting myelinated afferents that convey low 

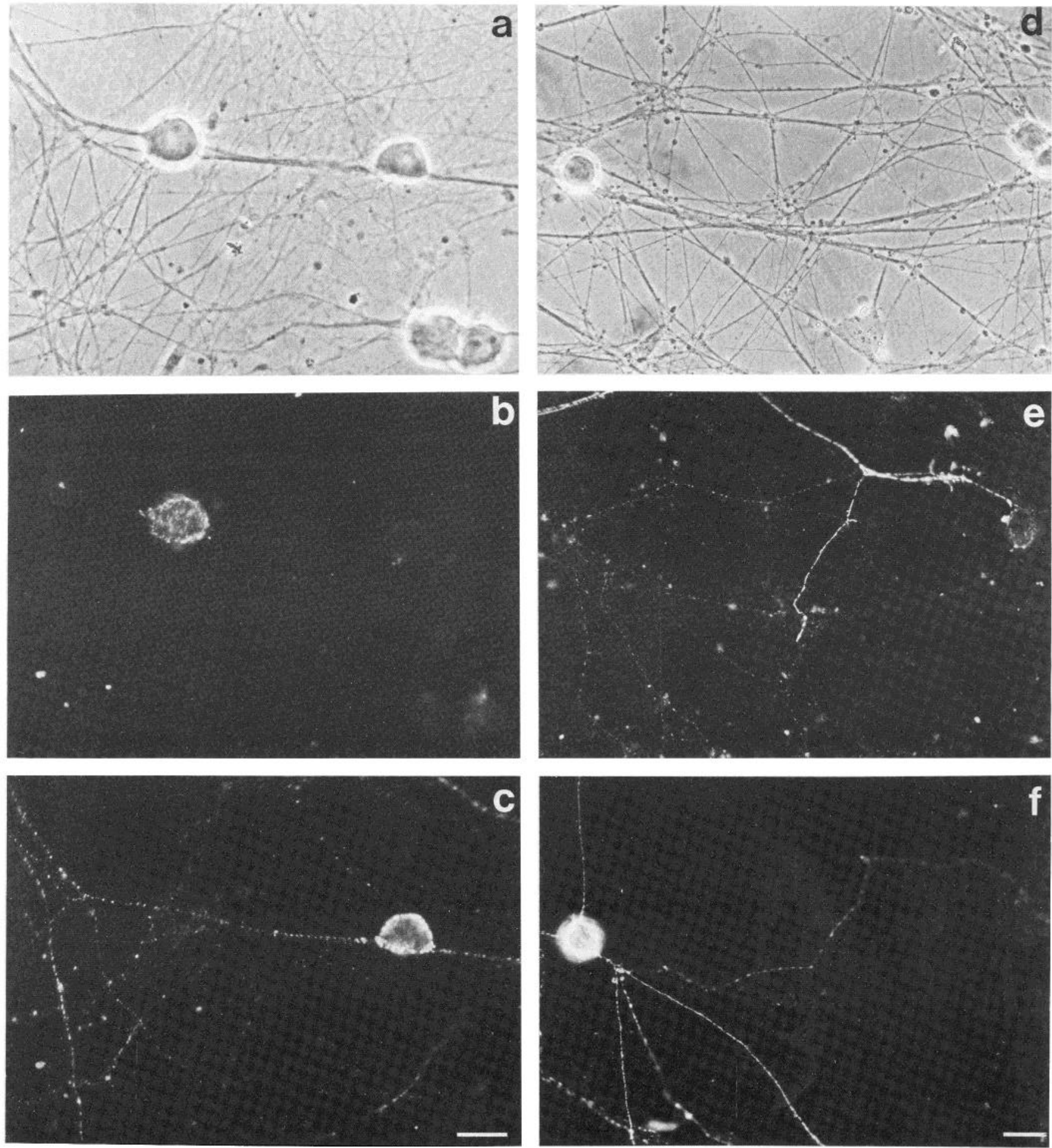

Figure 9. Separate populations of DRG neurons in culture express globo- and lactoseries carbohydrates on their surface. $a$, Phase contrast micrograph of DRG neurons in culture. This culture was incubated with MAbs A5 and anti-SSEA-4. FITC-goat anti-mouse lgM and Rh-rabbit anti-mouse lgG3 were used to detect A5 and anti-SSEA-4, respectively. b. Fluoresence micrograph (FITC) of the same field showing that MAb A5 labels only one of the four neurons in the field. The A5 ${ }^{+}$neuron is SSEA-4- (see c). c. Fluorescence micrograph of the same field (Rh) showing that one of the other neurons is SSEA-4 ${ }^{+}$but $A 5^{-}$. Two other neurons are A5-/SSEA-4-.$d$, Phase contrast micrograph of DRG neurons in culture. This culture was incubated with MAbs LA4 and anti-SSEA4. $e$, One neuron and many processes are LA4 $4^{+}$. The $L A 4^{+}$neuron is SSEA- $4^{-} . f$, A different neuron in the field is SSEA- $4^{+} / \mathrm{LA}^{-}$. Note that some SSEA ${ }^{+}$ and $\mathrm{LA}_{4}^{+}$neuritic processes appear to run together in fiber bundles. Calibration bars, $15 \mu \mathrm{m}$.

threshold cutaneous input project to laminae III and IV (Brown, 1981). The localization of globoseries carbohydrates on afferent fibers in the dorsal columns and dorsal column nuclei (Dodd et al., 1984) is also consistent with the expression of globoseries determinants by low threshold myelinated afferents. The distribution of afferent fibers expressing lactoseries determinants in the superficial dorsal horn is consistent with their identity as $\mathrm{C}$ and perhaps some $\mathrm{A} \delta$ fibers (Fig. 10) (Rethelyi, 1977; Gobel et al., 1981). Lamina I was the only region where convergence of afferents expressing globoseries and lactoseries antigens was observed. These findings are consistent with 


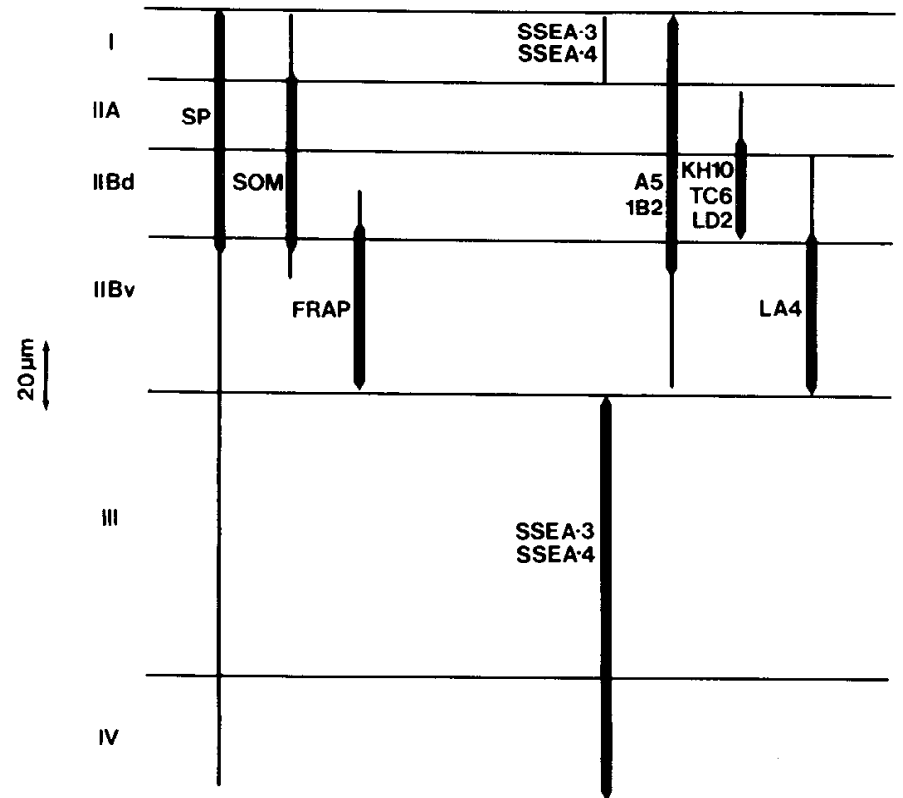

Figure 10. Comparison of the dorsal horn lamina termination site of primary afferent fibers expressing DRG cell surface carbohydrate differentiation antigens with the distribution of SP and SOM immunoreactivity and FRAP enzyme reaction product. The region of densest immunoreactivity is designated by the wide bar. The lamina scheme in rat dorsal horn is derived from our own analysis and from Ribiero Da Silva and Coimbra (1982) and Nagy and Hunt (1983).

physiological observations indicating that lamina I receives input from myelinated and unmyelinated primary afferents that convey different sensory modalities (Bennett et al., 1981; Rethelyi et al., 1982).

One of the most striking findings in these studies was the relationship between carbohydrate expression and the peptide and enzyme phenotype of small DRG neurons. The fact that several lactoseries carbohydrate antigens are segregated according to peptide expression suggests that there may be a co-ordinate regulation of peptide transmitters and cell surface carbohydrates in DRG neurons. The expression of complex lactoseries carbohydrate antigens in subsets of $\mathrm{SP}^{+}$and $\mathrm{FRAP}^{+}$DRG neurons also provides direct evidence for chemical diversity within $\mathrm{SP}^{+}$and $\mathrm{FRAP}^{+}$DRG neuronal populations. Other observations suggest that the presence of SP and FRAP may not be restricted to functionally or chemically homogeneous neuronal populations within DRG. SP immunoreactivity has been observed in both myelinated and unmyelinated fibers in the superficial dorsal horn (DiFiglia et al., 1982) and in association with free endings and Meissner's corpuscles in skin (Dalsgaard et al., 1983). Two distinct patterns of enzyme reaction product are present within FRAP ${ }^{+}$DRG neurons (Dodd et al., 1983a). The restricted expression of carbohydrate antigens in subsets of $\mathrm{SP}^{+}$and FRAP' DRG neurons may therefore correspond to functionally distinct subsets of these neurons.

Many intrinsic spinal and supraspinal neurons that project to the superficial dorsal horn express SP and SOM. It is therefore difficult to compare the extent of the laminar distribution of afferents identified by carbohydrate antigens and neuropeptides. The inclusion of all $\mathrm{SOM}^{+} \mathrm{DRG}$ neurons in the class of neurons labeled by the MAbs $\mathrm{KH} 10$ and LD2 provides evidence for a more restricted dorsal horn termination pattern of $\mathrm{SOM}^{+}$DRG neurons than has been revealed by immunocytochemical localization of the peptide itself (Fig. 10).

In total, more than $80 \%$ of DRG neurons can be labeled with MAbs directed against globo- and lactoseries determinants (Tables II and III). Biochemical and immunological studies on other cell types have demonstrated that the backbone globo- and lactoseries carbohydrate sequences can be associated with a much greater diversity of carbohydrate structures than we have so far been able to analyze with available MAbs (Feizi, 1984; Hakomori, 1984; Magnani, 1984). It is likely, therefore, that DRG neurons that are not labeled with the MAbs used in our studies express alternative complex globo- or lactoseries carbohydrate structures.

Although the distribution of carbohydrate antigens has been analyzed in most detail in the rat, we found that similar or identical carbohydrate structures are present on subsets of primary sensory neurons in many other vertebrate species. The SSEA-3 and SSEA-4 determinants are present on a similar proportion of DRG neurons and have a similar lamination pattern in the dorsal horn in other strains of rats, in other rodents, and in cats, primates, and certain avian species. The backbone lactoseries sequence recognized by MAbs A5 and 1B2/1B7 is also found in subsets of DRG neurons in cats, prirrates, and birds, although a detailed analysis of these neurons has not yet been performed. Recent studies have demonstrated that structurally related lactoseries antigens that correspond to the ABO blood group phenotype of the tissue donor are selectively expressed on subsets of DRG neurons in primates and humans (Oriol, 1983; Oriol et al., 1984). These results establish that there is a high degree of conservation in the expression of globo- and lactoseries carbohydrate structures by subpopulations of DRG neurons in vertebrates.

We also detected globo- and lactoseries carbohydrate antigens on other classes of primary sensory neurons and on some specialized sensory transduction cells. Olfactory sensory neurons expressed lactoseries antigens present on DRG neurons (J. Dodd and T. M. Jessell, manuscript in preparation). In addition, taste bud cells in the fungiform and vallate papillae expressed the lactoseries carbohydrates (unpublished observations). These findings indicate a remarkable association of lactoseries carbohydrate structures with sensory neurons and sensory transduction cells. The localization of blood group $\mathrm{H}$ and $\mathrm{B}$ antigens on rat olfactory sensory neurons and on primary receptor hair cells in the inner ear has also been described recently by Molliconc et al. (1985), suggesting that, unlike DRG neurons, primary sensory cells of the olfactory and auditory system can express $\mathrm{H}$-gene-dependent carbohydrate structures.

Both globo- and lactoseries carbohydrate antigens were expressed on the surface of neonatal DRG neurons maintained in culture and on adult DRG neurons. Of the MAbs directed against epitopes associated with linear blood group B-reactive lactoseries carbohydrates, only MAb 2C5 did not label the surface of cultured DRG neurons. This observation suggests that the linear $B$ structure on the surface of DRG neurons is modified by the addition of saccharides that abolish reactivity with MAb $2 \mathrm{C} 5$ but not with the MAbs KH10, LD2, or LA4 (Fig. 11). Some evidence for modification in the synthesis of lactoseries carbohydrates by rat DRG neurons maintained in culture was obtained with MAb anti-SSEA-1. The SSEA1 determinant was expressed on the surface of 10 to $15 \%$ of cultured DRG neurons, although the same determinant was detectable in less than $0.1 \%$ of neurons in sections of neonatal or adult DRG in situ, with no evidence of surface staining. These results suggest that there is an induction of $\alpha(1,3)$-fucosyltransferase activity on DRG neurons maintained in culture. $\alpha(1,3)$-Fucosylation of the Gal $\beta 1-4 G l c N A c-R$ structure has been shown to inhibit terminal galactose addition by the B-gene-specified $\alpha(1,3)$-galactosyltransferase (Watkins, 1980). Inhibition of this galactosyltransferase enzyme could account for the low percentage of cultured DRG neurons labeled by the MAbs $\mathrm{KH} 10$ and $\mathrm{LD} 2$, which require the $\alpha 1,3$-galactosyl structure. The factors that lead to the induction of the SSEA-1 antigen on cultured DRG neurons are not yet clear. The studies in culture, however, clearly demonstrate that globo- and lactoseries carbohydrate antigens are present on the surface of distinct subsets of DRG neurons.

The expression of globo- and lactoseries structures by DRG neurons appears to be related to their embryologic origin. Developmental studies in avian species indicate that primary sensory neurons within DRG can be divided into two major neuronal subtypes: a population of large, early-differentiating ventrolateral cells and a 


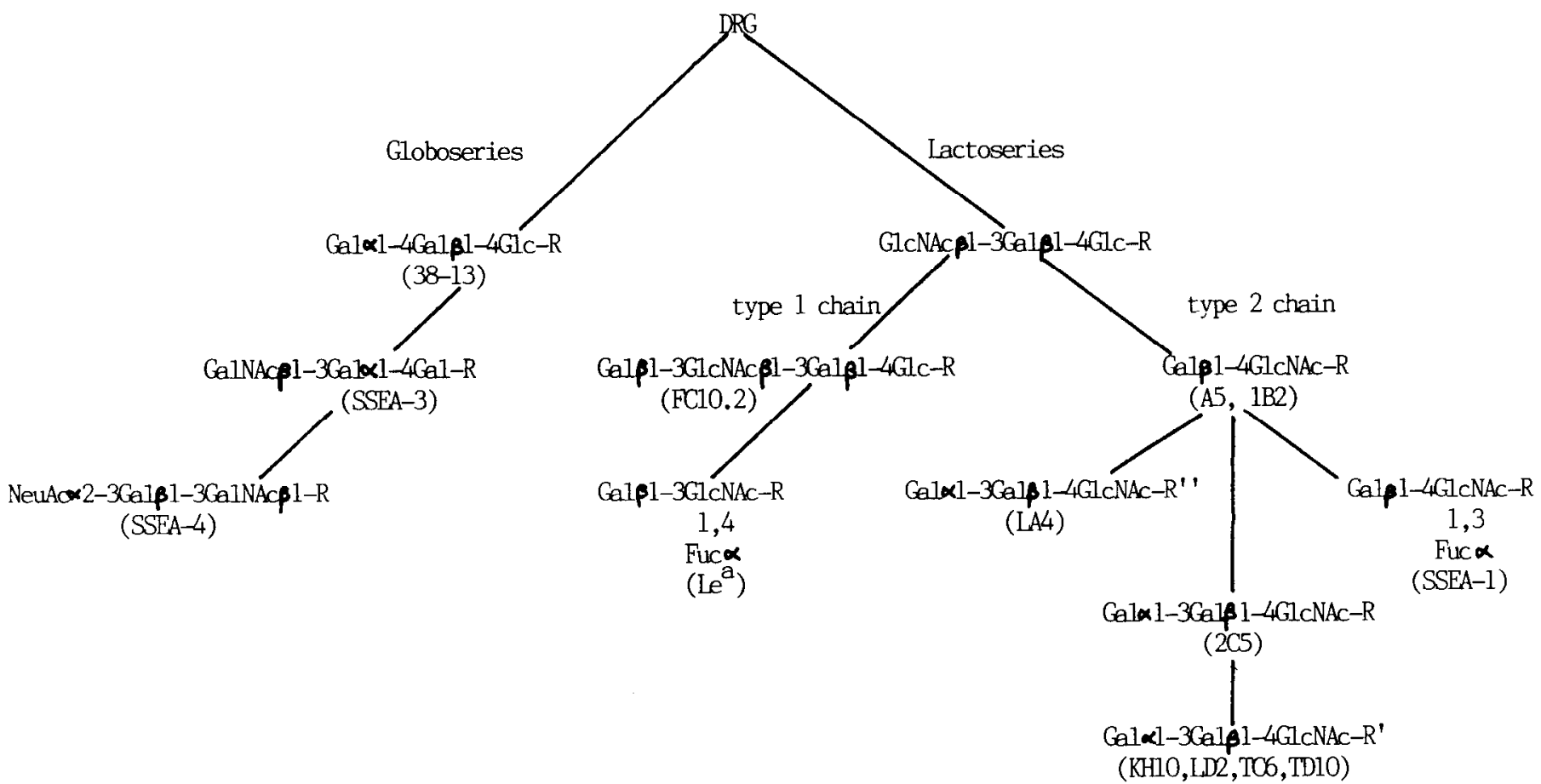

Figure 11. Scheme of the possible synthetic pathways that generate the carbohydrate epitopes recognized by MAbs that label the cytoplasm and surface of subsets of rat DRG neurons. This scheme is tentative and is based on the known epitope specificity of the MAbs shown, and information on the synthetic pathways that lead to the generation of the same carbohydrate determinants on human erythrocytes (Watkins, 1980). Pathways that generate carbohydrate determinants that are not expressed by rat DRG neurons are not shown.

second class of small, later-differentiating dorsomedial cells (Hamburger et al., 1981). Morphological studies in mammalian species have also demonstrated the existence of two distinct neuronal populations termed large light (LL) and small dark (SD) (Lawson et al., 1984). Globoseries carbohydrate structures appear to be associated predominantly with the $\mathrm{LL}$ cell population in DRG and with placodally derived cranial sensory neurons. The distribution of lactoseries carbohydrates in DRG and cranial sensory ganglia is consistent with a preferential association with SD DRG neurons and neural crest-derived cranial sensory neurons. Since the glycosyl transferases that are required for the synthesis of the carbohydrate antigens on DRG neurons are expressed at very early stages of embryonic development (Stern, 1984), it is possible that sensory neuron-specific carbohydrate antigens will represent useful markers for studying the early lineage and differentiation of DRG neurons.

The function of globo- and lactoseries carbohydrate antigens on mammalian cell surfaces is not clear at present. The regulation of globo- and lacloseries carbohydrate structures during embryonic development and differentiation has been examined particularly intensively in recent years. The sequential, stage-dependent expression of both lactoseries and globoseries carbohydrates has been described in early preimplantation murine embryos (Solter and Knowles, 1978; Kapadia et al., 1981; Knowles et al., 1982; Willison et al., 1982; Kannagi et al., 1983b; Feizi, 1984; Stern, 1984). Initial expression of the lactoseries carbohydrate antigen recognized by MAb anti-SSEA-1 immediately precedes compaction of cleavagestage embryos (Solter and Knowles, 1978). Moreover, the addition of lacto- $N$-fucopentaose III, an oligosaccharide that expresses the SSEA-1 epitope, has been reported to reverse the calcium-independent phase of embryonic compaction and to inhibit subsequent blastocyst formation (Bird and Kimber, 1984; Fenderson et al., 1984). The ability of sugar haptens to inhibit or reverse compaction appears to bo sclective and is dependent on the presence of fucose $\alpha(1,3)$ or $\alpha(1,4)$ linkages (Bird and Kimber, 1984) and also on the valency of molecules expressing these carbohydrate structures (Fenderson et al., 1984). Antibodies directed against F9 teratocarcinoma antigens that are known to express SSEA-1-reactive carbohydrates have also been shown to inhibit embryonic compaction (Kemler et al., 1979). These studies suggest a functional, but still undefined, role in early embryonic development for one class of carbohydrate structure that is subsequently expressed on the surface of DRG neurons.

Cell surface glycoconjugates have also been implicated in adhesion between neural cells. A series of related cell adhesion molecules (CAMs) have been shown to mediate neuron-neuron and neuronglial adhesive interactions in the developing nervous system (Goridis et al., 1983; Edelman, 1984; Rutishauser, 1984). Immunological and biochemical studies have revealed a developmental regulation of the carbohydrate composition of $N$-CAM, and there is recent evidence that CAMs that mediate distinct adhesive interactions in the developing nervous syslem (Rathjen and Rutishauser, 1984) can be identified by MAbs that detect carbohydrate structures (Kruse et al., 1984). These observations suggest that both the total degree of glycosylation and the diversity of carbohydrate structures on cell adhesion molecules may contribute to the selectivity of neural interactions at specific times and within specific regions of the developing nervous system.

The expression by DRG neurons of globo- and lactoseries carbohydrates that have been implicated in cell-cell interaction during preimplantation embryonic development raises the possibility that molecules bearing these determinants might play similar roles in the development of spinal sensory systems. Since most of the globoand lactoseries structures we have examined are restricted to sensory neurons, interactions with spinal cord target cells may be mediated by the binding of sensory neuron carbohydrates to complementary cell surfacc molecules. Carbohydrate-binding proteins have been isolated from several vertebrate species (Barondes, 1984) and represent one class of molecules with the potential for interaction with carbohydrates on DRG neurons. Endogenous mammalian lectins exhibit a high affinity for lactoseries structures (Childs and Feizi, 1979; Sarkar et al., 1979) that we have shown to be present on the surface of subsets of rat DRG neurons. Moreover, this class of carbohydrate-binding protein is known to be developmentally regulated in vertebrate brain (Kobiler and Barondes, 1977) and spinal cord (Eisenbarth et al., 1978).

Although the interaction between spinal cord carbohydrate-bind- 
ing proteins and sensory neuron carbohydrates has not yet.been examined, some evidence suggests that it may be possible to modify the patterns of sensory input to the spinal cord with saccharide structures (Baker, 1983). The identification and localization of complex carbohydrate determinants that are expressed selectively on the surface of subsets of DRG neurons should make it possible to analyze the functional role of these molecules in the development of spinal sensory systems.

\section{References}

Baker, R. E. (1983) Effects of gangliosides on the development of selective afferent connections within fetal mouse spinal cord explants. Neurosci. Lett. 41: 81-84.

Barondes, S.H. (1984) Soluble lectins: A new class of extracellular proteins. Science 223: 1259-1264.

Bennet, G. J., M. Abdelmoumene, H. Hayashi, M. Hoffert, and R. Dubner (1981) Spinal cord layer 1 cells with axon collateral that generate local arbors. Brain Res. 209: 421-426.

Bird, J. M., and S. J. Kimber (1984) Oligosaccharides containing fucose linked $\alpha(1,3)$ and $\alpha(1,4)$ to $N$-acetylglucosamine cause decompaction of mouse morulae. Dev. Biol. 104: 449-460.

Blaineau, C., J. Le Pendu, D. Arnaud, F. Connan, and P. Avner (1983) The glycosidic antigen recognized by a novel monoclonal antibody $75-12$, is developmentally regulated on mouse embryonal carcinoma cells. EMBO J. 2: 2217-2222.

Brown, A. G. (1981) Organization in the Spinal Cord. Springer-Verlag, New York.

Brown, A. G., P. K. Rose, and P. J. Snow (1977) The morphology of hair follicle collaterals in the spinal cord of the cat. J. Physiol. (Lond.) 272: 779-797

Childs, R. A., and T. Feizi (1979) Calf heart lectin reacts with blood group li antigens and other precursor chains of the major blood group antigens. FEBS Lett. 99: 175-179.

Coackham, H. B., J. A. Garson, A. A. Harper, E. I. Harper, S. N. Lawson, and B. J. Randle (1982) Monoclonal antibody 2C5: A new marker for a subset of small neurons in the rat dorsal root ganglion. J. Physiol. (Lond.) 332: $60 \mathrm{P}$

Dalsgaard, C. J., C. E. Johnsson, T. Hokfelt, and A. C. Cuello (1983) Localization of substance $P$ immunoreactive nerve fibers in the human digital skin. Experienta 39: 1018-1020.

DiFiglia, M., N. Aronin, and S.E. Leeman (1982) Light microscopic and ultrastructural localization of immunoreactive substance $P$ in the dorsal horn of monkey spinal cord. Neuroscience $7:$ 1127-1139.

Dodd, J., and T. M. Jessell (1984) Monoclonal antibodies that identify functional subsets of primary sensory neurons. Soc. Neurosci. Abstr. 10: 734

Dodd, J., C. E. Jahr, and T. M. Jcsscll (1983a) Neurotransmitters and neuronal markers at sensory synapses in the dorsal horn. Adv. Pain Res. Ther. 6: 105-121.

Dodd, J., C. E. Jahr, P. N. Harnillurı, M. J. S. Heath, W. D. Matthew, and T. $M$. Jessell (1983b) Cytochemical and physiological properties of sensory and dorsal horn neurons that transmit cutaneous sensation. Cold Spring Harbor Symp. Quant. Biol. 48: 685-695.

Dodd, J., D. Solter, and T. M. Jessell (1984) Monoclonal antibodies against carbohydrate differentiation antigens identify subsets of primary sensory neurons. Nature 311: 469-472.

Edelman, G. (1984) Modulation of cell adhesion during induction, histogenesis, and perinatal development of the nervous system. Annu. Rev. Neurosci. 7: 339-377.

Eisenbarth, G. S., R. R. Ruffolo, F. S. Walsh, and M. Nirenberg (1978) Lactose sensitive lectin of chick retina and spinal cord. Biochem. Biophys. Res. Commun. 83: 1246-1252.

Feizi, T. (1984) Monoclonal antibodies reveal saccharide structures of glycoproteins and glycolipids as differentiation and tumour-associated antigens. Biochem. Soc. Trans. 12: 545-548.

Feizi, T., E. A. Kabat, G. Vicari, B. Anderson, and W. J. Marsh (1971) Immunochemical studies on blood groups. XLIX. The I antigen complex: Specificity differences among anti-I sera revealed by quantitative precipitation studies: partial structure of the I determinant specific for one anti-I serum. J. Immunol. 106: 1578-1592.

Fenderson, B. A., A. C. Hahnel, and E. M. Eddy (1983) Immunohistochemical localization of two monoclonal antibody defined carbohydrate antigens during early murine embryogenesis. Dev. Biol. 100: 318-327.

Fenderson, B. A., U. Zehari, and S. I. Hakomori (1984) A multivalent lacto- $N$ fucopentaose III-lysyllysine conjugate docompacts preimplantation mouse embryos, while the free oligosaccharide is ineffective. J. Exp. Med. 160 1591-1596.

Fukuda, M., and M. N. Fukuda (1984) Cell surface glycoproteins and carbohydrate antigens in development and differentiation of human eryth roid cells. In The Biology of Glycoproteins, R. J. Ivatt, ed., pp. 183-234, Plenum Press, New York.

Gobel, S., W. M. Falls, and E. Humphrey (1981) Morphology and syraptic connections of ultrafine primary axons in lamina l of the spinal dorsal horn: Candidates for the terminal axonal arbors of primary neurons with unmyelinated axons. J. Neurosci. 1: 1163-1179.

Gooi, H. C., T. Feizi, A. Kapadia, B. B. Knowles, D. Solter; and M. J. Evans (1981) Stage specific embryonic antigen involves $\alpha 1,3$ fucosylated type 2 blood group chains. Nature 292: 156-158.

Gooi, H. C., L. K. Williams, K. Uemura, E. F. Hounsell, R. Mcllhinney, and T. Feizi (1983) A marker of human foetal endoderm defined by a monoclona antibody involves type 1 blood group chains. Mol. Immunol. 20: 607-613. Goridis, C., H. Deagostini-Bazin, M. Hirn, M. R. Hirsch, S. Rougon, R. Sadoul, O. K. Langley, G. Gombos, and J. Finne (1983) Neural surface antigens during nervous system development. Cold Spring Harbor Symp. Quant. Biol. 48: 527-538.

Hakomori, S. I. (1984) Tumor associated carbohydrate antigens. Annu. Rev. Immunol. 2: 103-126.

Hamburger, V., J. K. Bruno-Bechtold, and J. W. Yip (1981) Neonatal death in the spinal ganglion of the chick embryo and its reduction by nerve growth factor. J. Neurosci. 1:60-71.

Hanfland, P., H. Egge, U. Dabrowski, S. Kuhn, D. Roelke, and J. Dabrowski (1981) Isolation and characterization of an I-active ceramide decasaccharide from rabbit erythrocyte membranes. Biochemistry 20: 5310-5319.

Hokfelt, T., R. Elde, O. Johansson, R. Luft, G. Nilsson, and A. Arimura (1976) Immunohistochemical evidence for separate populations of somatostatincontaining and substance $\mathrm{P}$ containing primary afferent neurons in the rat. Neuroscience 1: 131-139.

Iggo, A. (1976) Is the physiology of cutaneous receptors determined by morphology? Adv. Neurol. 4: 1-9.

Jessell, T. M., and J. Dodd (1985) Structure and expression of differentiation antigens on functional subclasses of primary sensory neurons. Philos. Trans. R. Soc. Lond. (Biol.) 308: 271-281.

Jessup, N. W. and R. J. Hay (1981) Characteristics of two rat pancreatic exocrine cell lines derived from transplantable tumors. In Vitro 16:212.

Kannagi, R., S. B. Levery, and S. I. Hakomori (1983a) Sequential change of carbohydrate antigens associated with differentiation of murine leukemia cells: il antigenic conversion and shifting of glycolipid synthesis. Proc. Natt. Acad. Sci. U. S. A. 80: 2844-2848.

Kannagi, R., S. B. Levery, F. Ishigami, S. I. Hakomori, L. H. Shevinsky, B. B. Knowles, and D. Solter (1983b) New globoseries glycolipids in human teratocarcinoma reactive with the monoclonal antibody directed to a developmentally regulated antigen-stage specific antigen 3 . J. Biol. Chem. 258: 8934-8942.

Kannagi, R., N. Cochran, F. Ishigami, S. I. Hakomori, P. W. Andrews, B. B. Knowles, and D. Solter (1983c) Stage-specific embryonic antigens (SSEA 3 and SSEA-4) are epitopes of a unique globoseries ganglioside isolated from human teratocarconoma cells. EMBO J. 2: 2355-2361.

Kapadia, A., T. Feizi, and M. J. Evans (1981) Changes in the expression and polarization of blood group $\mid$ and $i$ antigens in post-implantation embryos and teratocarcinomas of mouse associated with cell differentiation. Exp. Cell Res. 131: 185-195.

Kemler, R., C. Babinet, H. Eisen, and F. Jacob (1979) Surface antigen in early differentiation. Proc. Natl. Acad. Sci. U. S. A. 74: 4449-4453.

Knowles, B. B., J. Rappaport, and D. Solter (1982) Murine embryonic antigen SSEA-1 is expressed on human cells and structurally related human blood group antigen I is expressed on mouse embryos. Dev. Biol. 93: 54-58.

Kobiler, D., and S. H. Barondes (1977) Lectin activity from embryonic chick brain, heart and liver: Changes with development. Dev. Biol. 60: 326-330.

Kruse, J., R. Mailhammer, H. Wernecke, A. Faissner, I. Sommer, C. Goridis and M. Schachner (1984) Neural cell adhesion molecules and myelin associated glycoprotein share a common carbohydrate moeity recognized by monoclonal antibodies L2 and HNK-1. Nature 311: 153-155.

Lawson, S. N., K. W. T. Caddy, and T. J. Biscoe (1974) Development of rat dorsal root ganglion neurons. Studies of cell birthdays and changes in mean cell diameter. Cell Tissue Res. 153: 399-413.

Lawson, S. N., A. A. Harper, E. I. Harper, J. A. Garson, and B. H. Anderton (1984) A monoclonal antibody against neurofilament proteins specifically labels a subpopulation of rat sensory neurons. J. Comp. Neurol. 228: 262-272.

Light, A. R., and E. R. Perl (1979) Spinal termination of functionally identified primary afferent fibres with slowly conducting myelinated fibres. J. Comp. Neurol. 186: 133-150. 
Light, A. R., and E. R. Perl (1984) Peripheral sensory systems. In Peripheral Neuropathy, P. Dyck, $\Gamma$. Thomas, C. H. Lambert, and R. Bunge, eds., pp. 210-230, W. B. Saunders Co., Philadelphia.

Lloyd, K. O., G. Lawson, N. Stromberg, J. Thurin, and K. A. Karlsson (1983) Mouse monoclonal antibody $F-3$ recognizes the difucosyl type 2 blood group structure. Immunogenetics 17: 537-541.

Magnani, J. L. (1984) Carbohydrate differentiation and cancer-associated antigens detected by monoclonal antibodies. Biochem. Soc. Trans. 12. $543-545$

Mirsky, R. (1982) The use of antibodies to define and study major cell types in the central and peripheral nervous system. In Neuroimmunology, J. Brockes, ed., pp. 141-181, Plenum Press, New York.

Mollicone, R., J. Trojan, and R. Oriol (1985) Appearence of H and B antigens in primary sensory cells of rat olfactory apparatus and inner ear. Dev. Brain Res., 17: 275-279.

Nagy, J. I, and S. P. Hunt (1982) Fluoride-resistant acid-phosphatase containing neurons in dorsal root ganglia are separate from those containing substance $P$ or somatostatin. Neuroscience $7:$ 89-97.

Nagy, J. I., and S. P. Hunt (1983) The termination of primary afferents within the rat dorsal horn: Evidence for rearrangement following capsaicin treatment. J. Comp. Neurol. 218: 145-158.

Nudelman, E., R. Kannagi, S. Hakomori, M. Parsons, M. Lipinski, J. Wiels, M. Fellous, and T. Tursz (1983) A glycolipid antigen associated with Burkitt lymphoma defined by a monoclonal antibody. Science 200: $509-511$.

Oriol, R. (1983) Immunofluorescent localization and genetic control of the synthesis of $\mathrm{ABH}$ and Lewis antigens. In Red Cell Membrane Glycoconjugates and Related Genetic Markers, J. P. Cartron, P. Rouger, and C. Salmon, eds., pp 139-149, Librairie Arnette, Paris.

Oriol, R., J. E. Cooper, D. R. Davies, and P. W. N. Keeling (1984) ABH antigens in vascular endothelium and some epithelial tissues of baboons. Lab. Invest. 50: 514-518.

Perl, E. R. (1983) Characterization of nociceptors and their activation of neurons in the superficial dorsal horn: First steps for the sensation of pair. Adv. Pain Res. Ther. 6: 23-51.

Raff, M. R.. K. L. Fields, S. I. Hakomori, R. M. Pruss, and J. Winter (1979) Cell-type specific markers for distinguishing and studying neurons and the major classes of glial cells in culture. Brain Res. 174: 283-308.

Ralston, H. J., A. R. Light, D. D. Ralston, and E. R. Perl (1984) Morphology and synaptic relationships of physiologically identified low-threshold dorsal root axons stained with intra-axonal horse-radish peroxidase in the cat and monkey. J. Neurophysiol. 51:777-792.

Rambourg, A., Y. Clermont, and A. Beaudet (1983) Ultrastructural features of six types of neurons in rat dorsal root ganglion. J. Neurocytol. 12: $47-$ 63.
Randle, B. J. (1982) Cosegregation of monoclonal antibody reactivity and cell behaviour in the mouse preirnplantation embryo. J. Embryol. Exp. Morphol. 70: 261-278.

Rathjen, F. G., and U. Rutishauser (1984) Comparison of two cell surface molecules involved in neural cell adhesion. EMBO J. 3: 461-465.

Renkonen, O. (1983) Polysaccharides of embryonal carcinoma cells of line PC 13. Biochem. Soc. Trans. 11: 265-267.

Rethelyi, M. (1977) Preterminal and terminal arborizations within substantia gelatinosa of cat spinal cord. J. Compl. Neurol. 172: 511-528.

Rethelyi, M., A. R., Light and E. R. Perl (1982) Synaptic complexes formed by functionally defined primary afferent units with fine myelinated fibers. J. Comp. Neurol. 207: 381-393.

Ribiero Da Silva, A., and A. Coimbra (1982) Two types of synaptic glomeruli and their distributions in laminae $\mathrm{I}-\mathrm{lll}$ of the rat spinal cord. J. Comp. Neurol. 209: 176-186

Rutishauser, U. (1984) Developmental biology of a neural cell adhesion molecule. Nature 310:549-554.

Sarkar, M., J. Liao, E. A. Kabat, T. Tanabe, and G. Ashwell (1979) The binding site of rabbit hepatic lectin. J. Biol. Chem. 254: 3170-31/4.

Semba, K., P. Masarachia, S. Melamed, M. Jacquin, S. Harris, G. Yang, and M. D. Egger (1983) An electron microscopic study of primary afferent terminals from slowly adapting type 1 receptors in the cat. J. Comp. Neurol. 221: 466-481.

Shevinsky, L. H., B. B. Knowles, I. Damjanov, and D. Solter (1982) Monoclonal antibody to murine embryos defines a stage-specific embryonic antigen expressed on mouse embryos and human teratocarcinoma cells. Cell 30: $697-705$

Solter, D., and B. B. Knowles (1978) Monoclonal antibody defining a stage specific embryonic antigen (SSEA-1). Proc. Natl. Acad. Sci. U. S. A. 75: 55655569.

Stern, P. (1984) Differentiation antigens of teratomas and embryos. Br. Med. Bull. 40: 218-223.

Watkins, W. M. (1980) Biochemistry and genetics of the ABO, Lewis and $P$ blood group systems. Adv. Human Genet. 10: 1-136.

Willison, K. R., R. A. Karol, A. Suzuki, S. K. Kundu, and D. M. Marcus (1982) Neutral glycolipid antigens as developmental markers of mouse teratocarcinomas and early embryos: An immunologic and chemical analysis. J. Immunol. 129: 603-611

Yamamoto, M., H. W. M. Steinbusch, and T. M. Jessell (1981) Differentiated properties of identified serotonin neurons in dissociated cultures of embryonic rat brain stem. I Cell Biol $91 \cdot 142-152$

Young, W. W., J. Portoukalian, and S. Hakomori (1981) Two monoclonal carbohydrate antibodies directed to glycosphingolipids with a lacto- $N$ glycosyl type II chain. J. Biol. Chom. 256: 10967-10972. 